Prepared for the U.S. Department of Energy

under Contract DE-AC05-76RL01830

\title{
Abiotic Degradation Rates for Carbon Tetrachloride and Chloroform: Progress in FY 2010
}

$\begin{array}{ll}\text { JE Amonette } & \text { DR Humphrys } \\ \text { PM Jeffers } & \text { TW Wietsma } \\ \text { O Qafoku } & \text { MJ Truex } \\ \text { CK Russell } & \end{array}$

December 2010

\section{Pacific Northwest}

NATIONAL LABORATORY

Proudly Operated by Battelle Since 1965 


\title{
DISCLAIMER
}

This report was prepared as an account of work sponsored by an agency of the United States Government. Neither the United States Government nor any agency thereof, nor Battelle Memorial Institute, nor any of their employees, makes any warranty, express or implied, or assumes any legal liability or responsibility for the accuracy, completeness, or usefulness of any information, apparatus, product, or process disclosed, or represents that its use would not infringe privately owned rights. Reference herein to any specific commercial product, process, or service by trade name, trademark, manufacturer, or otherwise does not necessarily constitute or imply its endorsement, recommendation, or favoring by the United States Government or any agency thereof, or Battelle Memorial Institute. The views and opinions of authors expressed herein do not necessarily state or reflect those of the United States Government or any agency thereof.

\author{
PACIFIC NORTHWEST NATIONAL LABORATORY \\ operated by \\ BATTELLE \\ for the \\ UNITED STATES DEPARTMENT OF ENERGY \\ under Contract DE-AC05-76RL01830
}

Printed in the United States of America
Available to DOE and DOE contractors from the Office of Scientific and Technical Information, P.O. Box 62, Oak Ridge, TN 37831-0062; ph: (865) 576-8401 fax: $(865) 576-5728$
email: reports@adonis.osti.gov
Available to the public from the National Technical Information Service 5301 Shawnee Rd., Alexandria, VA 22312 ph: (800) 553-NTIS (6847) email: orders $a$ ntis.gov $<$ http://www.ntis.gov/about/form.aspx> Online ordering: http://www.ntis.gov




\section{Abiotic Degradation Rates for Carbon Tetrachloride and Chloroform: Progress in FY 2010}

$\begin{array}{ll}\text { JE Amonette } & \text { DR Humphrys } \\ \text { PM Jeffers } & \text { TW Wietsma } \\ \text { O Qafoku } & \text { MJ Truex } \\ \text { CK Russell } & \end{array}$

December 2010

Prepared for the U.S. Department of Energy under Contract DE-AC05-76RL01830

Pacific Northwest National Laboratory Richland, Washington 99352

\footnotetext{
${ }^{1}$ The Research Foundation of the State University of New York, Cortland, New York.
} 


\begin{abstract}
This report documents the progress made through FY 2010 on a project initiated in FY 2006 to help address uncertainties related to the rates of hydrolysis in groundwater at the Hanford Site for carbon tetrachloride (CT) and chloroform (CF). The study also explores the possible effects of contact with minerals and sediment (i.e., heterogeneous hydrolysis) on these rates. The research was initiated to decrease the uncertainties in abiotic degradation rates of CT and chloroform $\mathrm{CF}$ associated with temperature and possible heterogeneous effects. After 2 years of data collection, the first evidence for heterogeneous effects was identified for hydrolysis of CT, and preliminary evidence for the effects of different mineral types on CF hydrolysis rates also was reported. The CT data showed no difference among mineral types, whereas significant differences were seen in the CF results, perhaps due to the fact that CF hydrolyzes by both neutral and base-catalyzed mechanisms whereas CT follows only the neutral hydrolysis path.

In this report, we review the project objectives, organization, and technical approaches taken, update the status and results of the hydrolysis-rate experiments after 4 years of experimentation (i.e., through FY 2010), and provide a brief discussion of how these results add to scientific understanding of the behavior of the CT/CF plume at the Hanford Site.
\end{abstract}




\section{Abbreviations}

$\begin{array}{ll}\text { CF } & \text { chloroform } \\ \text { CHPRC } & \text { CH2M HILL Plateau Remediation Company } \\ \text { CT } & \text { carbon tetrachloride } \\ \text { DOE } & \text { U.S. Department of Energy } \\ \text { IRMS } & \text { isotope ratio mass spectrometry } \\ \text { PNNL } & \text { Pacific Northwest National Laboratory } \\ \text { RSD } & \text { relative standard deviation } \\ \text { SUNY-Cortland } & \text { State University of New York at Cortland } \\ \text { ZHR } & \text { zero-headspace reactor }\end{array}$




\section{Contents}

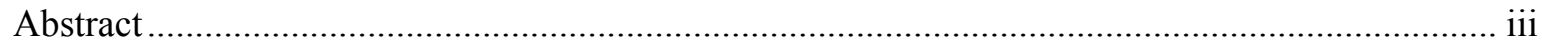

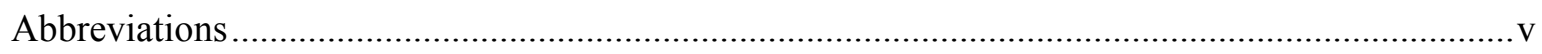

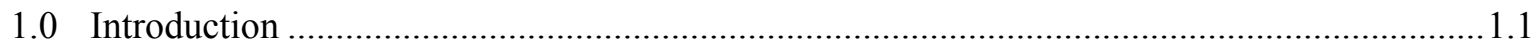

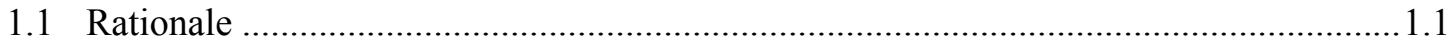

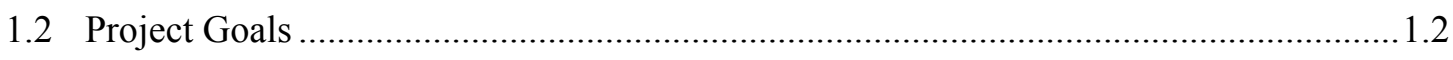

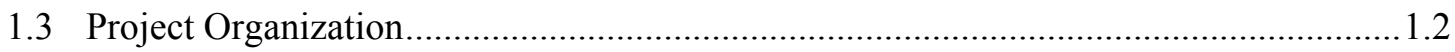

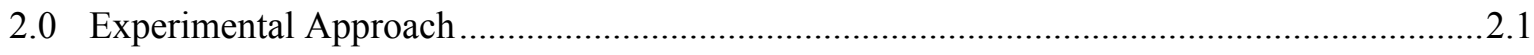

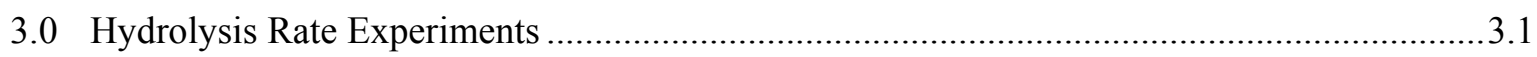

3.1 Homogeneous Experiments with Carbon Tetrachloride …........................................... 3.1

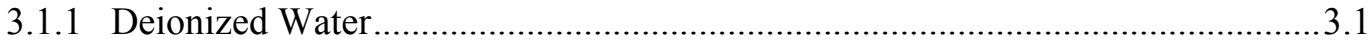

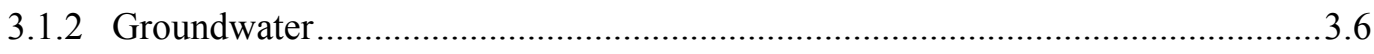

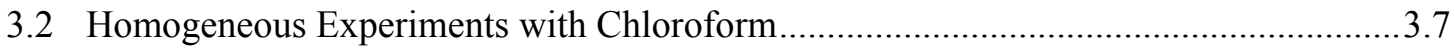

3.3 Heterogeneous Experiments with Carbon Tetrachloride …..........................................11

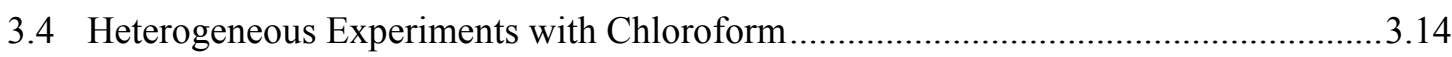

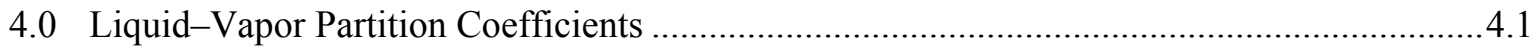

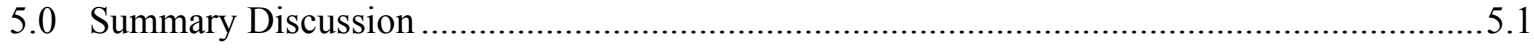

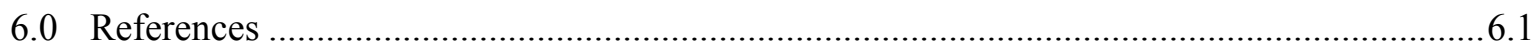




\section{Figures}

3.1 Arrhenius Plot of $\mathrm{k}_{\text {zhs }}$ Data Generated in This Study Along with $\mathrm{k}_{\text {app }}$ Data as Reported by Jeffers et al. and the 1996 Data Normalized to $\mathrm{k}_{\mathrm{zhs}}$ Assuming a 2\% Headspace-to-Liquid Ratio and the Extrapolated Henry's Law Coefficients of Gossett

3.2 Arrhenius Plot of All Homogeneous Hydrolysis Data for Chloroform .................................. 3.8

3.3 Arrhenius Plot of Base-Catalyzed Homogeneous Hydrolysis Data for Chloroform......

3.4 Impact of Temperature and $\mathrm{pH}$ on Hydrolysis Half-life Predicted for Chloroform From Homogeneous Rate Data Developed in This Project

3.5 Arrhenius Plot of $\mathrm{k}_{\mathrm{zhs}}$ Data for Hydrolysis of Carbon Tetrachloride in Deionized Water, Hanford Groundwater, and Suspensions of Oxidized Hanford Sediment in Hanford Groundwater

3.6 Provisional $\mathrm{k}_{\mathrm{PFO}}$ Data at $50^{\circ} \mathrm{C}$ for Hydrolysis of Chloroform in Suspensions of Minerals or Hanford Sediment and Calculated for Homogeneous Solutions at Several pH Levels

4.1 Infrared Gas Cell and Spectrometer Used in the Liquid-Vapor Partition Coefficient Determinations at PNNL

4.2 Plot of Typical Absorbance Data for Successive Equilibrations of CT in the Partition Coefficient Determination

4.3 Linear Relation Between Log of Absorbance and Equilibration Number

4.4 Values of $\mathrm{K}_{\mathrm{H}^{\prime}}$ Determined and Extrapolated to Higher Temperatures from Gossett and Staudinger \& Roberts, Together with Direct Determinations of $\mathrm{K}_{\mathrm{lv}}$ at SUNY-Cortland and PNNL, and Back-Calculated Values of $\mathrm{K}_{\mathrm{lv}}$ Derived from PNNL Hydrolysis-Rate Determinations in Deionized Water

4.5 $\Psi_{\mathrm{x}}-$ Normalized Values of $\mathrm{K}_{\mathrm{H}^{\prime}}$ Determined and Extrapolated to Higher Temperatures from Gossett and Staudinger \& Roberts, Together with Direct Determinations of $\mathrm{K}_{\mathrm{lv}}$ at SUNYCortland and PNNL, and Back-Calculated Values of $\mathrm{K}_{\mathrm{lv}}$ Derived from PNNL HydrolysisRate Determinations in Deionized Water....

4.6 Mean Values of $\mathrm{K}_{\mathrm{lv}}$ for Chloroform Measured by SUNY-Cortland and PNNL, Together with $\mathrm{K}_{\mathrm{h}}$ Values for Chloroform Reported by Gorgenyi et al. and Predicted by Staudinger \& Roberts. 


\section{Tables}

3.1 Status of PNNL Carbon Tetrachloride Hydrolysis Experiments ........................................... 3.1

3.2 Provisional Rate Constants for Hydrolysis of Carbon Tetrachloride in Deionized Water ........ 3.2

3.3 Rate Constants for Hydrolysis of Carbon Tetrachloride in Deionized Water at High

Temperatures as Reported by Jeffers et al. and as Corrected for an Assumed 2\%

Headspace-to-Liquid Ratio Using Extrapolated Values of $\mathrm{K}_{\mathrm{H}}{ }^{\prime}$ from Gossett

3.4 Provisional Arrhenius Parameters for Hydrolysis of Carbon Tetrachloride in Deionized

Water and Corresponding Provisional Half-Lives Estimated for $16^{\circ} \mathrm{C}$.

3.5 Provisional Half-Life Values for Hydrolysis of Carbon Tetrachloride in Deionized Water Based on Rate Constants Listed in Table 3.2

3.6 Provisional Rate Constants for Hydrolysis of Carbon Tetrachloride in Hanford Groundwater.

3.7 Provisional Half-Life Values for Hydrolysis of Carbon Tetrachloride in Hanford Site Groundwater Based on Rate Constants Listed in Table 3.6

3.8 Status of PNNL Homogeneous Chloroform Hydrolysis Experiments ................................... 3.7

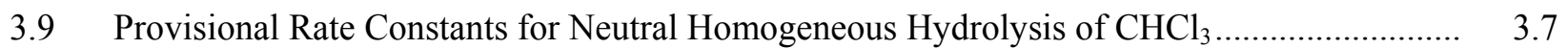

3.10 Provisional Rate Constants for Base-Catalyzed Homogeneous Hydrolysis of $\mathrm{CHCl}_{3} \ldots \ldots \ldots \ldots \ldots . . . . .8$

3.11 Status of PNNL Heterogeneous Carbon Tetrachloride Hydrolysis Experiments in Hanford Groundwater.

3.12 Provisional Rate Constants for Hydrolysis of Carbon Tetrachloride in Suspensions of Hanford Site Sediment in Hanford Groundwater.

3.13 Provisional Half-Life Values for Hydrolysis of Carbon Tetrachloride in Suspensions of Hanford Site Sediment in Hanford Site Groundwater Based on Rate Constants in Table 3.11

3.14 Provisional Rate Constants for Hydrolysis of Carbon Tetrachloride in Suspensions of Minerals in Hanford Groundwater

3.15 Status of PNNL Heterogeneous Chloroform Hydrolysis Experiments in Hanford Groundwater Started in FY 2007 and FY 2008.

3.16 Status of PNNL Heterogeneous Chloroform Hydrolysis Experiments at pH 7.2 in Hanford Groundwater Started in FY 2009.

3.17 Provisional Pseudo-First-Order Rate Constants for Hydrolysis of Chloroform in Suspensions of Hanford Sediment or Specific Minerals in Hanford Groundwater. 


\subsection{Introduction}

This report documents the progress made through FY 2010 on a project initiated in FY 2006 to help address uncertainties related to the rates of hydrolysis in groundwater for carbon tetrachloride and chloroform. The study seeks also to explore the possible effects of contact with minerals and sediment (i.e., heterogeneous hydrolysis) on these rates. In previous years, the work was funded as two separate projects by various sponsors, all of whom received their funding from the U.S. Department of Energy (DOE). In FY 2009, the projects were combined and funded by CH2M HILL Plateau Remediation Company. Starting in FY 2009 all work was performed by staff at the Pacific Northwest National Laboratory (PNNL). Staff from the State University of New York at Cortland (SUNY-Cortland) contributed in previous years.

\subsection{Rationale}

Between 1955 and 1973, an estimated $920,000 \mathrm{~kg}$ of carbon tetrachloride (CT) were discharged to the soil in the 200 West Area of the Hanford Site as part of the plutonium production process (Oostrom et al. 2007). Of this amount, some CT reached the groundwater more than $70 \mathrm{~m}$ below the ground surface and formed a plume of $10 \mathrm{~km}^{2}$ extent. Recent data show that the CT plume extends to a depth of at least $60 \mathrm{~m}$ below the water table. Some CT has been degraded by either the original process or subsequent transformations in the subsurface to form a coexisting plume of chloroform (CF).

Upcoming remediation decisions will rely on an improved conceptual model of the plume as well as mechanistic information concerning the fate and transport of CT/CF. A key aspect of these decisions will be to determine the relative sizes of the efforts devoted to active remediation and natural attenuation in order to stabilize the plume. Of the possible natural-attenuation mechanisms, biodegradation is not likely to contribute significantly (Truex et al. 2001), and mechanisms such as dispersion, dilution, and sorption to Hanford Site sediments have been the focus of previous field and modeling efforts (e.g., Riley et al. 2005). In contrast, abiotic-degradation processes such as hydrolysis and reduction, which are likely to contribute significantly to natural attenuation (Truex et al. 2001), are not well understood or quantified. The work in this project is designed to partly bridge that gap by determining the mechanisms and rates associated with hydrolysis.

Current estimates of chlorinated-methane hydrolysis rates are based on studies conducted at high temperatures (typically $70^{\circ} \mathrm{C}-150^{\circ} \mathrm{C}$ ) and extrapolated to ambient conditions using the Arrhenius equation. The use of data extrapolated from higher temperatures to estimate hydrolysis rates at groundwater temperatures injects considerable uncertainty into any attempt to determine the role of abiotic processes in CT and CF degradation and frustrates the development and design of possible remedies. To resolve this situation, collection of hydrolysis rate data at temperatures at or near actual groundwater temperatures is needed. Because the hydrolysis rates are very slow at low temperatures, adequate resolution of the issue requires a lengthy experiment (as long as 5 years), extremely accurate sampling and analytical procedures, control of temperature and microbial populations, adequate headspace in the vials to minimize pressure effects, and a large number of replicates. Not surprisingly, the combination of these requirements has inhibited the collection of these data at ambient temperatures heretofore. 
In addition to the uncertainty associated with temperature, the possibility of heterogeneous catalytic effects on hydrolysis rates exists. In 1994, Jeffers et al. reported on a search for heterogeneous catalysis in the hydrolysis of trichloroethene, tetrachloroethene, and 1,1,1-trichloroethane. In experiments executed at $102^{\circ} \mathrm{C}$ or $106^{\circ} \mathrm{C}$, no additional hydrolysis reactivity was observed with aqueous solutions containing finely divided dispersions of eleven different minerals (Jeffers et al. 1994). However, any catalytic process would be characterized by a lower activation energy, implying that Arrhenius curves for homogeneous and heterogeneous reactions could cross at some relatively low temperature, and in any case, a heterogeneous reaction path would become increasingly important as temperature decreased due to the increased probability of sorption.

This study was initiated to decrease the uncertainties in abiotic degradation rates of CT and CF associated with temperature and possible heterogeneous effects. After 2 years of data collection, the first evidence for heterogeneous effects was identified for hydrolysis of $\mathrm{CT}^{1}$, and preliminary evidence for the effects of different mineral types on CF hydrolysis rates also was reported (Amonette et al. 2009). Interestingly, the $\mathrm{CT}$ data showed no difference among mineral types, whereas significant differences were seen in the CF results, perhaps due to the fact that CF hydrolyzes by both neutral and base-catalyzed mechanisms whereas CT follows only the neutral hydrolysis path.

In this report, we review the project objectives, organization, and technical approaches taken, update the status and results of the hydrolysis-rate experiments after 3 years of experimentation (i.e., through FY 2010), and provide a brief discussion of how these results add to scientific understanding of the behavior of the CT/CF plume at the Hanford Site.

\subsection{Project Goals}

The overall goals of this project are to

1. Determine the homogeneous rates of hydrolysis for CT and CF (including neutral and base-catalyzed rates) in deionized water and Hanford Site groundwater at temperatures from $20^{\circ} \mathrm{C}$ to $70^{\circ} \mathrm{C}$.

2. Determine the Arrhenius parameters (i.e., activation energy and prefactor) for hydrolysis of CT and $\mathrm{CF}$ in aqueous systems using the hydrolysis rate data collected at temperatures of $20^{\circ} \mathrm{C}$ to $70^{\circ} \mathrm{C}$ together with previously published data, thus allowing highly accurate interpolated estimates of hydrolysis rate at any temperature in the $20^{\circ}-150^{\circ} \mathrm{C}$ range and reasonable extrapolation to groundwater temperatures.

3. Determine the impact and mechanisms of fine-grained Hanford Site sediment in Hanford groundwater and of representative Hanford mineral surfaces on the hydrolysis of CT and CF at nearambient temperatures.

\subsection{Project Organization}

Since its inception, the project has been managed by Jim Amonette (PNNL), who also has served as co-principal investigator with Peter Jeffers (SUNY-Cortland) and Mike Truex (PNNL). In FY 2010,

\footnotetext{
${ }^{1}$ Amonette JE, PM Jeffers, O Qafoku, CK Russell, TW Wietsma, and MJ Truex. Abiotic Degradation Rates for Carbon Tetrachloride: Progress in FY 2008. 2008 Draft Report, Pacific Northwest National Laboratory, Richland, Washington.
} 
work on the project was being conducted solely in the Environmental Molecular Sciences Laboratory at PNNL using ampules with a headspace-to-liquid ratio of 1:2. Before FY 2009, work was conducted also at SUNY-Cortland using minimal-headspace ampules (headspace-to-liquid ratio of about 1:50) and a zero-headspace reactor. The SUNY-Cortland work also included direct determinations of aqueous-vapor partition coefficients for CT and CF using a specially built reactor. 


\subsection{Experimental Approach}

The overall experimental design involves collection of data at four to six temperatures covering the range of $20^{\circ} \mathrm{C}-70^{\circ} \mathrm{C}$. Samples are incubated under one of three environments (sterile deionized water, sterile filtered Hanford 200-Area groundwater, or sterile Hanford 200-Area sediment in 200-Area groundwater), at one of two initial concentrations (40 ppm or $400 \mathrm{ppm}$ ), for periods of up to 5 years. We conduct five replicate analyses for each treatment combination at each of ten times during the experiment. Reaction progress is followed by measurement (using ion chromatography) of the chloride released. Two additional replicates are prepared as controls for potential analysis by gas chromatography in the event that non-hydrolytic degradation pathways are suspected. In addition, another 14 ampules are prepared for each temperature/environment combination to ascertain initial and maximum potential concentrations of chloride. Thus, the number of ampules for a temperature/environment combination is 84 .

Over the course of the project, 99 temperature/environment combinations (a total of more than 8300 ampules) have been started at PNNL; 46 of those combinations are still being actively sampled, although more than three-fourths of the ampules have been analyzed. The experiments under way included CT in deionized water and Hanford groundwater, and in groundwater suspensions of Hanford sediment or one of four representative mineral phases. For $\mathrm{CF}$, homogeneous experiments at three $\mathrm{pH}$ levels were started, of which only $\mathrm{pH} 3$ and $\mathrm{pH} 8$ remain due to the rapid degradation rates at $\mathrm{pH} 12$, as was an identical set of heterogeneous experiments involving Hanford sediment and the four representative minerals.

Details of the laboratory procedures used and calculations followed, together with analyses of the groundwater, sediment, and representative minerals, are given in Amonette et al. (2009). 


\subsection{Hydrolysis Rate Experiments}

In this section, we report all the data collected from the inception of the project in FY 2006 through FY 2010, in order to keep a complete record of the dataset. In addition, values listed are provisional and change as new information from sampling of more ampules in a temperature/environment combination becomes available.

\subsection{Homogeneous Experiments with Carbon Tetrachloride}

A total of four hydrolysis experiments are under way at PNNL, of which two are for hydrolysis in deionized water and two in Hanford groundwater. A fifth experiment, involving hydrolysis in a suspension of Hanford Site sediment in Hanford groundwater, is complete. Table 3.1 shows the status of the experiments with respect to sampling as of 30 September 2010 . Experiments at $30^{\circ} \mathrm{C}$ and higher have been fully sampled and analyzed. Hydrolysis rates are quite slow at $20^{\circ} \mathrm{C}$, and 1 more year will be required for these experiments.

Table 3.1. Status of PNNL Carbon Tetrachloride Hydrolysis Experiments

\begin{tabular}{|c|c|c|c|c|c|}
\hline & $\begin{array}{c}\text { Deionized } \mathrm{H}_{2} \mathrm{O} \text {, } \\
9.8 \text { ppm CT }\end{array}$ & $\begin{array}{c}\text { Deionized } \mathrm{H}_{2} \mathrm{O} \\
152 \mathrm{ppm} \mathrm{CT}\end{array}$ & $\begin{array}{c}\text { Hanford } \\
\text { Groundwater, } \\
35 \text { ppm CT }\end{array}$ & $\begin{array}{c}\text { Hanford } \\
\text { Groundwater, } \\
424 \text { ppm CT }\end{array}$ & $\begin{array}{l}\text { Hanford Sediment in } \\
\text { Groundwater, } \\
371 \text { ppm CT }\end{array}$ \\
\hline Temperature, ${ }^{\circ} \mathrm{C}$ & \multicolumn{5}{|c|}{-------------Fraction of experiment sampled as of 30 September 2010------------- } \\
\hline 20 & 90 & 90 & 80 & 80 & 60-completed \\
\hline 30 & 100 & 100 & 100 & 100 & 100 \\
\hline 40 & 100 & 100 & 100 & 100 & 100 \\
\hline 50 & 100 & 100 & 100 & 100 & 100 \\
\hline 60 & 100 & 100 & 100 & 100 & -- \\
\hline 70 & 100 & 100 & 100 & 100 & -- \\
\hline
\end{tabular}

At SUNY-Cortland, more than 35 kinetics experiments have been completed, including data at temperatures up to $93^{\circ} \mathrm{C}$ for correlation with the previous data reported by Jeffers et al. (1996). Only data from the most reliable of these experiments are reported here.

\subsubsection{Deionized Water}

The data available at the writing of this report are for hydrolysis at temperatures from $30^{\circ} \mathrm{C}$ to $93^{\circ} \mathrm{C}$. These are summarized in Table 3.2. For the PNNL data, both $\mathrm{k}_{\text {app }}$ and $\mathrm{k}_{\mathrm{ZHS}}$ [normalized using $\mathrm{K}_{\mathrm{H}}{ }^{\prime}$ values from Gossett (1987)] are reported. We note that the data of Gossett (1987) were collected at temperatures of $10^{\circ} \mathrm{C}-35^{\circ} \mathrm{C}$. We used the parameters fitted by Gossett to extrapolate his results to the higher temperatures in our study. Although we have conducted experiments to measure $\mathrm{K}_{\mathrm{H}}{ }^{\prime}$ values at relevant temperatures, further results are needed before we decide which set of $\mathrm{K}_{\mathrm{H}}{ }^{\prime}$ values are valid for our conditions (see Section 4). As a consequence, all rate constant values must be considered provisional pending further review of the data. 
Table 3.2. Provisional Rate Constants for Hydrolysis of Carbon Tetrachloride in Deionized Water

\begin{tabular}{|c|c|c|c|c|c|}
\hline Temperature, ${ }^{\circ} \mathrm{C}$ & $\begin{array}{c}\text { Initial } \mathrm{CCl}_{4} \\
\text { Concentration, } \mathrm{mg} \mathrm{L}^{-1}\end{array}$ & $\begin{array}{c}\mathrm{k}_{\mathrm{zhs}}, \\
\text { SUNY, } \mathrm{s}^{-1}\end{array}$ & $\begin{array}{c}\mathrm{k}_{\mathrm{zhh}}, \\
\text { PNNL, } \mathrm{s}^{-1}\end{array}$ & $\begin{array}{c}\mathrm{k}_{\text {app }}, \\
\text { PNNL, } \mathrm{s}^{-1}\end{array}$ & $\begin{array}{c}\mathrm{K}_{\mathrm{H}}^{\prime}, \\
\text { Gossett (1987) }\end{array}$ \\
\hline 93.0 & 340 & $3.50 \mathrm{e}-6$ & -- & -- & -- \\
\hline 88.0 & 163 & $1.98 \mathrm{e}-6$ & -- & -- & -- \\
\hline 80.5 & 62 & $8.50 \mathrm{e}-7$ & -- & -- & -- \\
\hline 70.0 & 369 & $2.42 \mathrm{e}-7$ & -- & -- & -- \\
\hline 70.0 & 350 & $2.30 \mathrm{e}-7$ & -- & -- & -- \\
\hline 70.0 & 152 & -- & $3.59 \mathrm{e}-7$ & $7.77 \mathrm{e}-8$ & 7.432 \\
\hline 70.0 & 9.8 & -- & $4.38 \mathrm{e}-7$ & $9.48 \mathrm{e}-8$ & 7.432 \\
\hline 60.0 & 323 & $5.63 \mathrm{e}-8$ & -- & -- & -- \\
\hline 60.0 & 152 & -- & $8.19 \mathrm{e}-8$ & $2.31 \mathrm{e}-8$ & 5.205 \\
\hline 60.0 & 9.8 & -- & $8.78 \mathrm{e}-8$ & $2.48 \mathrm{e}-8$ & 5.205 \\
\hline 50.0 & 323 & $1.40 \mathrm{e}-8$ & -- & -- & -- \\
\hline 50.0 & 301 & $1.34 \mathrm{e}-8$ & -- & -- & -- \\
\hline 50.0 & 152 & -- & $1.62 \mathrm{e}-8$ & $5.91 \mathrm{e}-9$ & 3.562 \\
\hline 50.0 & 9.8 & -- & $1.92 \mathrm{e}-8$ & $7.03 e-9$ & 3.562 \\
\hline 40.0 & 314 & $2.18 \mathrm{e}-9$ & -- & -- & -- \\
\hline 40.0 & 152 & -- & $3.52 \mathrm{e}-9$ & $1.51 \mathrm{e}-9$ & 2.377 \\
\hline 40.0 & 9.8 & -- & $2.36 \mathrm{e}-9$ & $1.09 \mathrm{e}-9$ & 2.377 \\
\hline 30.0 & 290 & $3.59 \mathrm{e}-10$ & -- & -- & -- \\
\hline 30.0 & 321 & $4.00 \mathrm{e}-10$ & -- & -- & -- \\
\hline 30.0 & 152 & -- & $8.14 \mathrm{e}-10$ & $4.65 \mathrm{e}-10$ & 1.543 \\
\hline 25.0 & 460 & $1.62 \mathrm{e}-10$ & -- & -- & -- \\
\hline 20.0 & 152 & -- & $8.29 \mathrm{e}-11$ & $5.63 e-11$ & 0.971 \\
\hline
\end{tabular}

The earlier high-temperature data published by Jeffers et al. (1996) were not corrected for headspace, as this was assumed to have negligible effect in his minimum headspace bulbs. Recent measurements of the headspace in similar bulbs suggest that a headspace-to-liquid ratio of 0.02 would make a reasonable estimate for the earlier work. To help compare the values obtained in the current project with those from the earlier work, we have calculated $\mathrm{k}_{\mathrm{zhs}}$ values for the Jeffers et al. (1996) data by the same approach used for the PNNL data. These are summarized in Table 3.3.

To visualize the current data in comparison to the earlier high-temperature data of Jeffers et al. (1996), all the $\mathrm{k}_{\mathrm{zhs}}$ values are shown in an Arrhenius plot along with the $\mathrm{k}_{\text {app }}$ values for the hightemperature data (Figure 3.1). From this plot, it is immediately apparent that the high-temperature data on the upper left-hand side of the plot are significantly affected by the headspace correction, even with only $2 \%$ headspace. When these data are extrapolated to lower temperatures (dashed lines), better agreement with the 2010 data is obtained for the headspace-corrected 1996 data than for the original $k_{\text {app }}$ data reported by Jeffers et al. (1996). 
Table 3.3. Rate Constants for Hydrolysis of Carbon Tetrachloride in Deionized Water at High Temperatures as Reported by Jeffers et al. (1996) ( $\left.\mathrm{k}_{\text {app }}\right)$ and as Corrected for an Assumed 2\% Headspace-to-Liquid Ratio Using Extrapolated Values of $\mathrm{K}_{\mathrm{H}}{ }^{\prime}$ from Gossett (1987) $\left(\mathrm{k}_{\mathrm{zhs}}\right)$

\begin{tabular}{lcccc}
\hline Temperature, ${ }^{\circ} \mathrm{C}$ & $\begin{array}{c}\text { Nominal Initial } \mathrm{CCl}_{4} \\
\text { Concentration, } \mathrm{mg} \mathrm{L}^{-1}\end{array}$ & $\mathrm{k}_{\mathrm{zhs}}, \mathrm{s}^{-1}$ & $\mathrm{k}_{\text {app }}, \mathrm{s}^{-1}$ & $\begin{array}{c}\mathrm{K}_{\mathrm{H}}{ }^{\prime}, \mathrm{Gossett} \\
(1987)\end{array}$ \\
\hline 163.0 & 40 & $2.94 \mathrm{e}-3$ & $1.04 \mathrm{e}-3$ & 90.634 \\
163.0 & 40 & $2.05 \mathrm{e}-3$ & $7.29 \mathrm{e}-4$ & 90.634 \\
149.7 & 40 & $9.25 \mathrm{e}-4$ & $3.92 \mathrm{e}-4$ & 67.973 \\
142.5 & 40 & $4.34 \mathrm{e}-4$ & $2.15 \mathrm{e}-4$ & 57.711 \\
130.9 & 40 & $1.73 \mathrm{e}-4$ & $9.19 \mathrm{e}-5$ & 43.789 \\
120.4 & 40 & $6.44 \mathrm{e}-5$ & $3.85 \mathrm{e}-5$ & 33.601 \\
110.6 & 40 & $2.55 \mathrm{e}-5$ & $1.68 \mathrm{e}-5$ & 25.870 \\
98.0 & 40 & $6.36 \mathrm{e}-6$ & $4.67 \mathrm{e}-6$ & 18.140 \\
85.0 & 40 & $1.04 \mathrm{e}-6$ & $8.36 \mathrm{e}-7$ & 12.199 \\
\hline
\end{tabular}

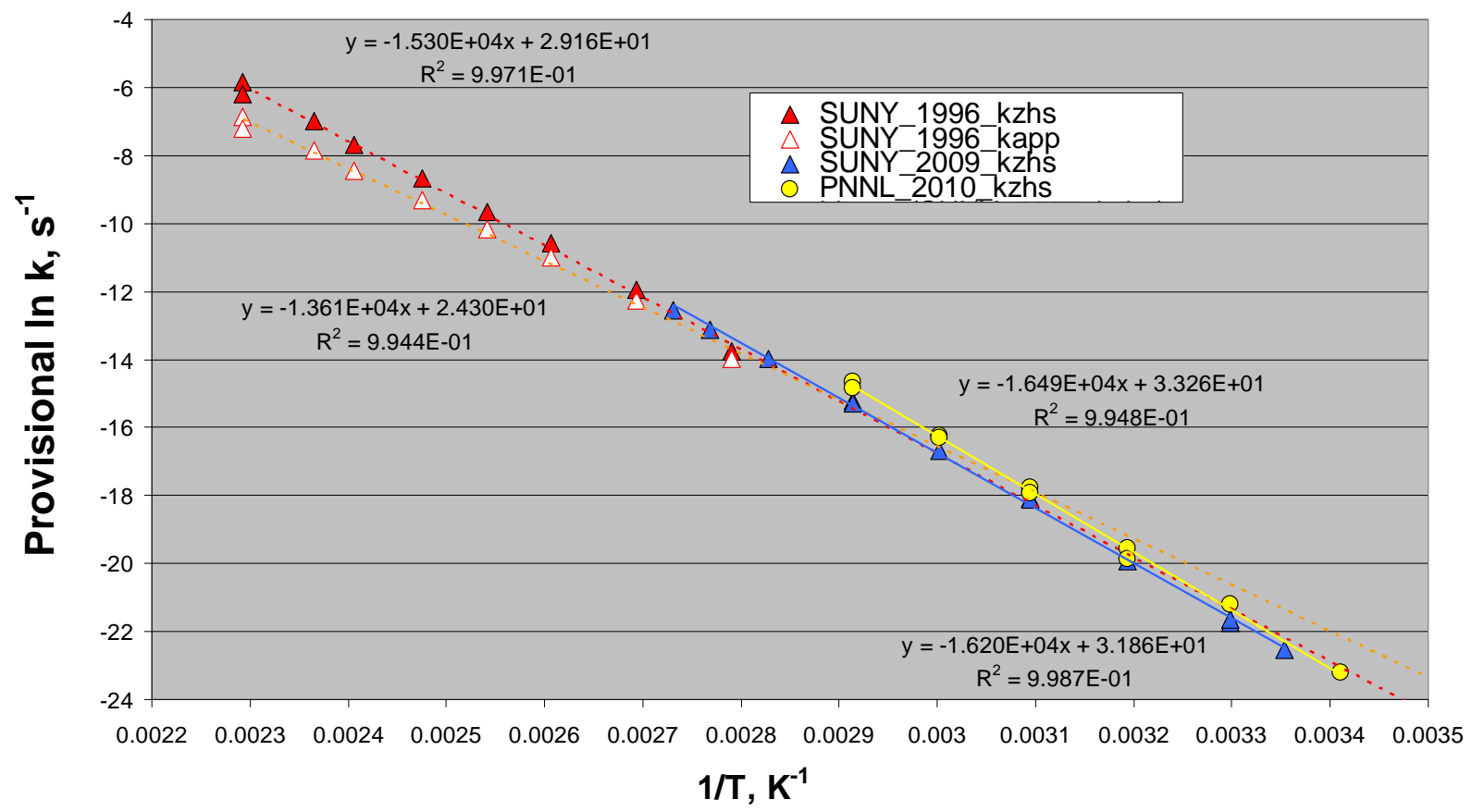

Figure 3.1. Arrhenius Plot of $\mathrm{k}_{\mathrm{zhs}}$ Data Generated in This Study (through 2010) Along with $\mathrm{k}_{\mathrm{app}}$ Data as Reported by Jeffers et al. (1996) and the 1996 Data Normalized to $k_{\text {zhs }}$ Assuming a 2\% Headspace-to-Liquid Ratio and the Extrapolated Henry's Law Coefficients of Gossett (1987). Blue triangles are SUNY data for deionized water using zero-headspace reactors.

On the lower right-hand side of Figure 3.1, the PNNL data are slightly, but consistently, higher than those from the SUNY zero-headspace reactor (ZHR) approach. And, while similar, the Arrhenius slope obtained for the PNNL ZHS-corrected dataset is slightly higher than that for the SUNY ZHR dataset. This difference is likely due to the extrapolated partition coefficient $\left(\mathrm{K}_{\mathrm{H}}{ }^{\prime}\right)$ used to estimate $\mathrm{k}_{\mathrm{zhs}}$ for the PNNL data, which would disproportionally affect the higher temperature data and lead to different 
Arrhenius slopes for the two approaches. We hope to resolve this issue in FY 2011 with completion of our measurements of $\mathrm{K}_{\mathrm{H}}{ }^{\prime}$.

Overall, the measured 2010 rate constants are slower than those that would have been predicted by extrapolation of the $1996 \mathrm{k}_{\text {app }}$ data to lower temperature (i.e., the dashed orange line in Figure 3.1). For example, the Arrhenius equation,

$$
\mathrm{k}=\mathrm{Ae}(\mathrm{Ea} / \mathrm{RT})
$$

where $\mathrm{A}$ is the pre-exponential factor $\left(\mathrm{s}^{-1}\right), \mathrm{E}_{\mathrm{a}}$ is the activation energy $\left(\mathrm{J} \mathrm{mol}^{-1}\right), \mathrm{R}$ is the gas constant $\left(8.314 \mathrm{~J} \mathrm{~mol}^{-1} \mathrm{~K}^{-1}\right)$, and $\mathrm{T}$ is the temperature $(\mathrm{K})$, predicts from the $1996 \mathrm{k}_{\text {app }}$ data a rate of $4.77 \mathrm{e}-9 \mathrm{~s}^{-1}$ at $40^{\circ} \mathrm{C}$, whereas the SUNY $\mathrm{k}_{\mathrm{zhs}}$ value measured is $2.18 \mathrm{e}-9 \mathrm{~s}^{-1}$, a factor of 2.2 slower. The gap between predicted and measured values increases to a factor of 3 at groundwater temperatures judging from the current trends in the data.

Values for $\mathrm{E}_{\mathrm{a}}$ and $\mathrm{A}$ determined from the regression lines in the Arrhenius plot (Figure 3.1) are summarized in Table 3.4. A single value for a $\mathrm{k}_{\mathrm{zhs}}$ dataset consisting of the normalized Jeffers et al. (1996), SUNY 2008, and PNNL 2008 datasets also is reported. These data show reasonable agreement in $\mathrm{E}_{\mathrm{a}}$ among the three separate $\mathrm{k}_{\mathrm{zhs}}$ datasets, as well as a substantial increase in $\mathrm{E}_{\mathrm{a}}$ and A over the values reported by Jeffers et al. (1996) for the $\mathrm{k}_{\text {app }}$ dataset.

Also shown in Table 3.4 are the corresponding half-lives at $16^{\circ} \mathrm{C}$ calculated using the Arrhenius parameters to estimate the rate constants and then inserting them into

$$
\mathrm{t}_{1 / 2}=\ln (2) / \mathrm{k}
$$

These clearly show the two- to three-fold differences between the original extrapolated data and those estimated from the current results. To reiterate, however, the current results are considered provisional pending resolution of the gas-liquid partitioning behavior in the PNNL experiments.

For comparison to previous published analyses that have represented rate constants as half-life values, we converted the rate constants shown in Table 3.2 to equivalent half-life values using Equation (3.2) and listed them in Table 3.5. 
Table 3.4. Provisional Arrhenius Parameters for Hydrolysis of Carbon Tetrachloride in Deionized Water and Corresponding Provisional Half-Lives Estimated for $16^{\circ} \mathrm{C}$

\begin{tabular}{lccc}
\hline Dataset & $\mathrm{E}_{\mathrm{a}}, \mathrm{kJ} \mathrm{mol}^{-1}$ & $\mathrm{~A}^{-1}$ & $\mathrm{t}_{1 / 2}\left(16^{\circ} \mathrm{C}\right), \mathrm{yr}$ \\
\hline Jeffers et al. (1996), $\mathrm{k}_{\text {app }}$ & 113 & $3.6 \mathrm{e} 10$ & 170 \\
Jeffers et al. (1996), $\mathrm{k}_{\text {zhs }}$ & 127 & $4.6 \mathrm{e} 12$ & 450 \\
SUNY 2009, $\mathrm{k}_{\text {zhs }}$ & 135 & $6.9 \mathrm{e} 13$ & 680 \\
PNNL 2010, $\mathrm{k}_{\text {zhs }}$ & 137 & $2.8 \mathrm{e} 14$ & 460 \\
All 2009-2010, $\mathrm{k}_{\text {zhs }}$ & 135 & $8.0 \mathrm{e} 13$ & 570 \\
All, $\mathrm{k}_{\text {zhs }}$ & 128 & $6.2 \mathrm{e} 12$ & 430
\end{tabular}

Table 3.5. Provisional Half-Life Values for Hydrolysis of Carbon Tetrachloride in Deionized Water Based on Rate Constants Listed in Table 3.2

\begin{tabular}{|c|c|c|c|c|c|}
\hline Temperature, ${ }^{\circ} \mathrm{C}$ & $\begin{array}{c}\text { Initial } \mathrm{CCl}_{4} \\
\text { Concentration, } \mathrm{mg} \mathrm{L}^{-1}\end{array}$ & $\begin{array}{c}\mathrm{t}_{1 / 2} \text { using } \mathrm{k}_{\mathrm{zhs}}, \\
\text { SUNY,yr }\end{array}$ & $\begin{array}{c}\mathrm{t}_{1 / 2} \text { using } \mathrm{k}_{\mathrm{zhs}}, \\
\text { PNNL, yr }\end{array}$ & $\begin{array}{c}\mathrm{t}_{1 / 2} \text { using } \mathrm{k}_{\mathrm{app}}, \\
\text { PNNL, yr }\end{array}$ & $\mathrm{K}_{\mathrm{H}}^{\prime}$, Gossett (1987) \\
\hline 93.0 & 340 & 0.0063 & -- & -- & -- \\
\hline 88.0 & 163 & 0.011 & -- & -- & -- \\
\hline 80.5 & 62 & 0.026 & -- & -- & -- \\
\hline 70.0 & 369 & 0.091 & -- & -- & -- \\
\hline 70.0 & 350 & 0.095 & -- & -- & -- \\
\hline 70.0 & 162 & -- & 0.061 & 0.28 & 7.432 \\
\hline 70.0 & 10 & -- & 0.050 & 0.23 & 7.432 \\
\hline 60.0 & 323 & 0.39 & -- & -- & -- \\
\hline 60.0 & 162 & -- & 0.27 & 0.95 & 5.205 \\
\hline 60.0 & 10 & -- & 0.25 & 0.89 & 5.205 \\
\hline 50.0 & 323 & 1.6 & -- & -- & -- \\
\hline 50.0 & 301 & 1.6 & -- & -- & -- \\
\hline 50.0 & 162 & -- & 1.4 & 3.7 & 3.562 \\
\hline 50.0 & 10 & -- & 1.1 & 3.1 & 3.562 \\
\hline 40.0 & 314 & 10. & -- & -- & -- \\
\hline 40.0 & 162 & -- & 6.2 & 15. & 2.377 \\
\hline 40.0 & 10 & -- & 9.3 & 20. & 2.377 \\
\hline 30.0 & 290 & 61. & -- & -- & -- \\
\hline 30.0 & 321 & 55. & -- & -- & -- \\
\hline 30.0 & 162 & -- & 27. & 47. & 1.543 \\
\hline 25.0 & 460 & 140. & -- & -- & -- \\
\hline 20.0 & 162 & -- & 265. & 390. & 0.971 \\
\hline
\end{tabular}




\subsubsection{Groundwater}

The hydrolysis data for Hanford groundwater are summarized in Tables 3.6 (rate constants) and 3.7 (half-lives). As before, all data are provisional pending further evaluation and additional data.

Table 3.6. Provisional Rate Constants for Hydrolysis of Carbon Tetrachloride in Hanford Groundwater

\begin{tabular}{lccccc}
\hline Temperature, ${ }^{\circ} \mathrm{C}$ & $\begin{array}{c}\text { Initial CCl } \\
\text { Concentration, } \mathrm{mg} \mathrm{L}^{-1}\end{array}$ & $\begin{array}{c}\mathrm{k}_{\mathrm{zhs}}, \\
\mathrm{SUNY}, \mathrm{s}^{-1}\end{array}$ & $\begin{array}{c}\mathrm{k}_{\mathrm{zhs}}, \mathrm{PNNL}, \\
\mathrm{s}^{-1}\end{array}$ & $\begin{array}{c}\mathrm{k}_{\text {app }}, \\
\text { PNNL, } \mathrm{s}^{-1}\end{array}$ & $\begin{array}{c}\mathrm{K}_{\mathrm{H}}{ }^{\prime}, \text { Gossett } \\
(1987)\end{array}$ \\
\hline 70 & 424 & -- & $2.93 \mathrm{e}-7$ & $6.34 \mathrm{e}-8$ & 7.432 \\
70 & 35 & -- & $8.94 \mathrm{e}-7$ & $1.93 \mathrm{e}-7$ & 7.432 \\
60 & 402 & $4.67 \mathrm{e}-8$ & -- & -- & -- \\
60 & 424 & -- & $6.32 \mathrm{e}-8$ & $1.79 \mathrm{e}-8$ & 5.205 \\
60 & 35 & -- & $1.27 \mathrm{e}-7$ & $3.58 \mathrm{e}-8$ & 5.205 \\
50 & 424 & -- & $1.14 \mathrm{e}-8$ & $4.17 \mathrm{e}-9$ & 3.562 \\
50 & 35 & & $3.86 \mathrm{e}-8$ & $1.41 \mathrm{e}-8$ & 3.562 \\
48.6 & 464 & $1.38 \mathrm{e}-8$ & -- & -- & -- \\
40 & 424 & -- & $2.59 \mathrm{e}-9$ & $1.20 \mathrm{e}-9$ & 2.377 \\
40 & 35 & -- & $6.24 \mathrm{e}-9$ & $2.89 \mathrm{e}-9$ & 2.377 \\
30 & 424 & -- & $3.76 \mathrm{e}-10$ & $2.15 \mathrm{e}-10$ & 1.543 \\
\hline 20 & 424 & -- & $7.01 \mathrm{e}-11$ & $4.76 \mathrm{e}-11$ & 0.971 \\
\hline
\end{tabular}

Table 3.7. Provisional Half-Life Values for Hydrolysis of Carbon Tetrachloride in Hanford Site Groundwater Based on Rate Constants Listed in Table 3.6

\begin{tabular}{lcclcc}
\hline Temperature, ${ }^{\circ} \mathrm{C}$ & $\begin{array}{c}\text { Initial } \mathrm{CCl}_{4} \\
\text { Concentration, } \mathrm{mg} \mathrm{L}^{-1}\end{array}$ & $\begin{array}{c}\mathrm{t}_{1 / 2} \text { using } \mathrm{k}_{\text {zhs }}, \\
\text { SUNY, yr }\end{array}$ & $\begin{array}{c}\mathrm{t}_{1 / 2} \text { using } \mathrm{k}_{\text {zhs }}, \\
\text { PNNL, yr }\end{array}$ & $\begin{array}{c}\mathrm{t}_{1 / 2} \text { using } \mathrm{k}_{\text {app }}, \\
\text { PNNL, yr }\end{array}$ & $\begin{array}{c}\mathrm{K}_{\mathrm{H}}{ }^{\prime}, \mathrm{Gossett} \\
(1987)\end{array}$ \\
\hline 70 & 330 & & 0.075 & 0.35 & 7.432 \\
70 & 27 & & 0.025 & 0.11 & 7.432 \\
60 & 402 & 0.47 & & & -- \\
60 & 330 & & 0.35 & 1.2 & 5.205 \\
60 & 27 & & 0.17 & 0.61 & 5.205 \\
50 & 330 & & 1.9 & 5.3 & 3.562 \\
50 & 27 & & 0.57 & 1.6 & 3.562 \\
48.6 & 464 & & & -- \\
40 & 330 & & 8.5 & 18. & 2.377 \\
40 & 27 & & 3.5 & 7.6 & 2.377 \\
30 & 330 & & 58. & 100. & 1.543 \\
20 & 330 & 315. & 460. & 0.971 \\
\hline
\end{tabular}




\subsection{Homogeneous Experiments with Chloroform}

The status of the homogeneous chloroform hydrolysis experiments at PNNL as of September 2010 is summarized in Table 3.8. As each experiment involves sampling at 10 separate time periods, the progress is given in terms of the number of sampling periods that have occurred (i.e., percentage of the initial ampules filled that have been terminated). As can be seen, a total of four homogeneous hydrolysis experiments with $\mathrm{CF}$ have been started, two at $\mathrm{pH} 3$, one at $\mathrm{pH} 8$, and one at $\mathrm{pH} 12$. Hydrolysis is rapid at $\mathrm{pH} 12$, and those experiments are complete (Table 3.8). In addition, the highest-temperature experiments at $\mathrm{pH} 8\left(70^{\circ} \mathrm{C}\right.$ through $\left.40^{\circ} \mathrm{C}\right)$ and $\mathrm{pH} 3\left(70^{\circ} \mathrm{C}\right.$ through $\left.50^{\circ} \mathrm{C}\right)$ are complete (Table 3.8). At SUNY-Cortland, seven experiments at $\mathrm{pH} 12$ and temperatures between $22^{\circ} \mathrm{C}$ and $60^{\circ} \mathrm{C}$ were completed.

Table 3.8. Status of PNNL Homogeneous Chloroform Hydrolysis Experiments

\begin{tabular}{|c|c|c|c|c|}
\hline & $\begin{array}{c}\mathrm{pH} \mathrm{3,} 41 \mathrm{ppm} \mathrm{CF} \\
1 \mathrm{mM} \mathrm{H}_{2} \mathrm{SO}_{4}\end{array}$ & $\begin{array}{c}\mathrm{pH} 3,337 \mathrm{ppm} \mathrm{CF} \\
1 \mathrm{mM} \mathrm{H}_{2} \mathrm{SO}_{4}\end{array}$ & $\begin{array}{c}\text { pH 8, } 205 \text { ppm CF, } \\
0.1 \text { M phosphate }\end{array}$ & $\begin{array}{c}\mathrm{pH} 12,320 \text { ppm CF, } \\
0.1 \mathrm{M} \text { phosphate }\end{array}$ \\
\hline Temperature, ${ }^{\circ} \mathrm{C}$ & \multicolumn{4}{|c|}{----------- Percentage of experiment sampled as of 30 September 2010 ---------- } \\
\hline 70 & 100 & 100 & 100 & -- \\
\hline 60 & 100 & 100 & 100 & -- \\
\hline 50 & 100 & 100 & 100 & 100 \\
\hline 40 & 90 & 90 & 100 & 100 \\
\hline 30 & -- & 50 & 40 & 100 \\
\hline 20 & -- & 50 & 40 & 100 \\
\hline
\end{tabular}

The usable rate data from the homogeneous CF experiments are summarized in Table 3.9 and Table 3.10, along with the initial reactant concentrations and the dimensionless Henry's law constants derived from Gorgenyi et al. (2002). Note that all the PNNL data at pH 8 and 12 were collected in $0.1-\mathrm{m}$ phosphate buffers. An Arrhenius plot of the homogeneous CF experimental data is given in Figure 3.2. All rate constant values must be considered provisional pending further review of the data.

Table 3.9. Provisional Rate Constants for Neutral Homogeneous Hydrolysis of $\mathrm{CHCl}_{3}$

\begin{tabular}{lccc}
\hline $\begin{array}{l}\text { Temperature, } \\
{ }^{\circ} \mathrm{C}\end{array}$ & $\begin{array}{c}\text { Initial } \mathrm{CHCl}_{3} \text { Concentration, } \\
\mathrm{mg} \mathrm{kg}^{-1}\end{array}$ & $\begin{array}{c}\mathrm{k}_{\mathrm{N}}, \\
\mathrm{K}_{\mathrm{H}}{ }^{\prime}, \\
\text { GNNL }\left(1 \mathrm{mM} \mathrm{H}_{2} \mathrm{SO}_{4}\right), \mathrm{s}^{-1}\end{array}$ & $\begin{array}{c}\text { Gorgenyi et al. } \\
(2002)\end{array}$ \\
\hline 70 & 41 & $2.46 \mathrm{e}-9$ & 0.691 \\
70 & 337 & $2.81 \mathrm{e}-9$ & 0.691 \\
60 & 41 & $5.22 \mathrm{e}-10$ & 0.541 \\
60 & 337 & $6.51 \mathrm{e}-10$ & 0.541 \\
50 & 41 & $1.96 \mathrm{e}-10$ & 0.417 \\
50 & 337 & $1.50 \mathrm{e}-10$ & 0.417 \\
\hline 40 & 337 & $2.96 \mathrm{e}-11$ & 0.296 \\
\hline
\end{tabular}


Table 3.10. Provisional Rate Constants for Base-Catalyzed Homogeneous Hydrolysis of $\mathrm{CHCl}_{3}$

\begin{tabular}{|c|c|c|c|c|c|}
\hline Temperature, ${ }^{\circ} \mathrm{C}$ & $\begin{array}{c}\text { Initial } \mathrm{CHCl}_{3} \\
\text { Concentration, } \\
\mathrm{mg} \mathrm{kg}^{-1}\end{array}$ & $\begin{array}{c}\text { Initial } \mathrm{OH}^{-} \\
\text {Concentration, } \\
\text { mol kg }^{-1}\end{array}$ & $\begin{array}{l}\mathrm{k}_{\mathrm{B}}, \mathrm{SUNY} \\
\mathrm{kg} \mathrm{mol}^{-1} \mathrm{~s}^{-1}\end{array}$ & $\begin{array}{l}\mathrm{k}_{\mathrm{B}}, \mathrm{PNNL} \\
(0.1 \mathrm{~m} \\
\text { phosphate), } \\
\mathrm{kg} \mathrm{mol}^{-1} \mathrm{~s}^{-1}\end{array}$ & $\begin{array}{c}\mathrm{K}_{\mathrm{H}} \text { ', Gorgenyi } \\
\text { et al. (2002) }\end{array}$ \\
\hline 70 & 205 & $1.37 \mathrm{e}-6$ & -- & $3.52 \mathrm{e}-1$ & 0.691 \\
\hline 60 & 205 & $1.37 \mathrm{e}-6$ & -- & $6.49 \mathrm{e}-2$ & 0.541 \\
\hline 60 & 58 & $9.74 \mathrm{e}-3$ & $8.70 \mathrm{e}-3$ & -- & -- \\
\hline 55 & 157 & $9.59 \mathrm{e}-3$ & $4.55 \mathrm{e}-3$ & -- & -- \\
\hline 50 & 205 & $1.37 \mathrm{e}-6$ & -- & $9.46 \mathrm{e}-3$ & 0.417 \\
\hline 50 & 320 & $2.64 \mathrm{e}-2$ & -- & $3.78 \mathrm{e}-3$ & 0.417 \\
\hline 40 & 205 & $1.37 \mathrm{e}-6$ & -- & $1.38 \mathrm{e}-3$ & 0.296 \\
\hline 40 & 157 & $9.59 \mathrm{e}-3$ & $5.18 \mathrm{e}-4$ & -- & -- \\
\hline 40 & 58 & $9.74 \mathrm{e}-3$ & $5.18 \mathrm{e}-4$ & -- & -- \\
\hline 40 & 320 & $2.64 \mathrm{e}-2$ & -- & $6.78 \mathrm{e}-4$ & 0.296 \\
\hline 30.15 & 50 & $1.01 \mathrm{e}-2$ & $1.22 \mathrm{e}-4$ & -- & -- \\
\hline 30 & 190 & $9.74 \mathrm{e}-3$ & $1.00 \mathrm{e}-4$ & -- & -- \\
\hline 30 & 205 & $1.37 \mathrm{e}-6$ & -- & $1.74 \mathrm{e}-4$ & 0.209 \\
\hline 30 & 320 & $2.64 \mathrm{e}-2$ & -- & $6.42 \mathrm{e}-5$ & 0.209 \\
\hline 22 & 157 & $9.59 \mathrm{e}-3$ & $2.98 \mathrm{e}-5$ & -- & -- \\
\hline 20 & 205 & $1.37 \mathrm{e}-6$ & -- & $2.50 \mathrm{e}-5$ & 0.137 \\
\hline 20 & 320 & $2.64 \mathrm{e}-2$ & -- & $8.39 \mathrm{e}-6$ & 0.137 \\
\hline
\end{tabular}

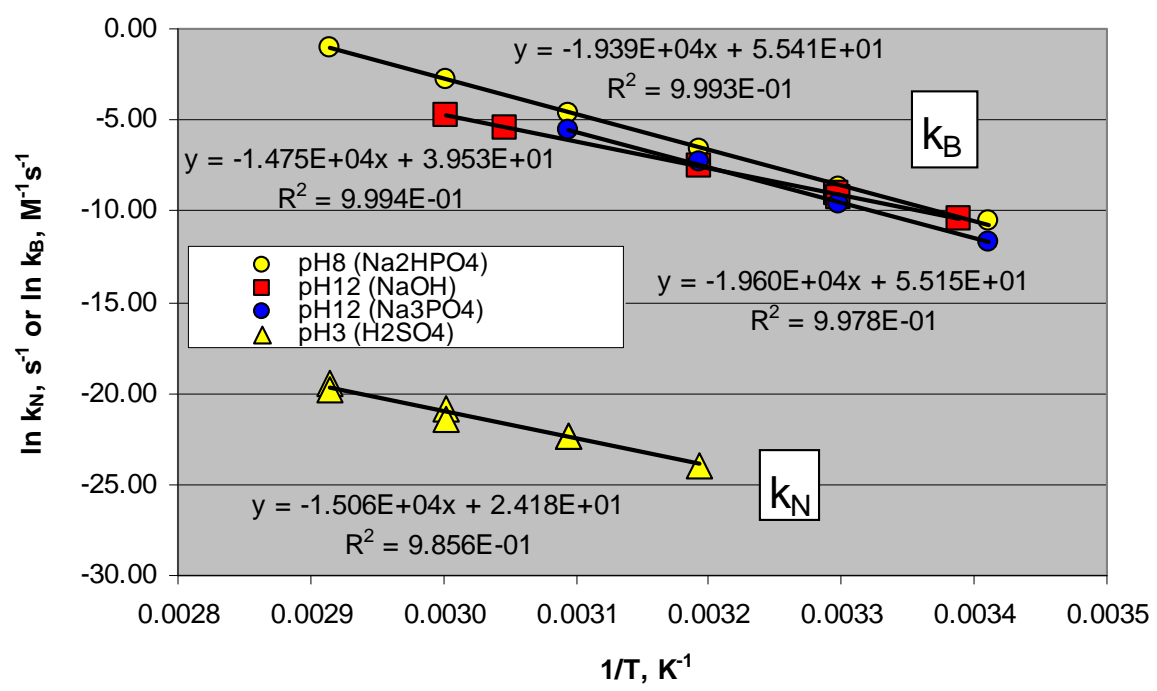

Figure 3.2. Arrhenius Plot of All Homogeneous Hydrolysis Data for Chloroform 
The overall hydrolysis rates are considerably slower at $\mathrm{pH} 8$ and temperatures below $40^{\circ} \mathrm{C}$ than at $\mathrm{pH}$ 12 , but the precision of these experiments has allowed us to obtain useful data down to $20^{\circ} \mathrm{C}$. At $\mathrm{pH} 3$, where only neutral hydrolysis is important, useful data are available from $70^{\circ} \mathrm{C}$ to $50^{\circ} \mathrm{C}$ at the lower concentration and from $70^{\circ} \mathrm{C}$ to $40^{\circ} \mathrm{C}$ at the higher concentration. At $30^{\circ} \mathrm{C}$, the data (not reported) are near the limit of detection, and at $20^{\circ} \mathrm{C}$ well below that limit. We propose terminating the $\mathrm{pH} 3$ experiments below $40^{\circ} \mathrm{C}$ as they are not likely to yield useful data within the time frame of this project.

The neutral hydrolysis results (Table $3.9, \mathrm{k}_{\mathrm{N}}$ in Fig. 3.2) show excellent agreement between the experiments conducted at the same temperature, even though the initial CF concentrations differ by a factor of ten. This result is consistent with expectations that solute concentration has negligible impact on liquid-vapor partition coefficients (Schwarzenbach et al. 1993, pp. 112-114) and hence on the amount of solute in contact with water, the hydrolyzing agent. As shown in Fig. 3.2, the neutral hydrolysis rate constants are roughly eight orders of magnitude smaller than the base-catalyzed rate constants $\left(\mathrm{k}_{\mathrm{B}}\right)$ given in Table 3.10.

An Arrhenius plot of the base-catalyzed homogeneous rate data is shown in Figure 3.3. One would expect similar $\mathrm{k}_{\mathrm{B}}$ values for the three experiments, and a fair agreement is observed. However, from this plot and Table 3.10, it is clear that the rates in the two phosphate-buffered systems have a similar temperature dependence that differs from the temperature dependence in $\mathrm{NaOH}$. This effect is due to the nucleophilic character of hydrogen phosphate $\left(\mathrm{HPO}_{4}{ }^{2-}\right)$ ion, which is about twice as great as that for hydroxyl ion, and thus can initiate hydrolysis-like reactions that would release $\mathrm{Cl}^{-}$ions to solution (Swain and Scott 1953; Schwarzenbach et al. 1993, pp. 359-365). Differences in the speciation of phosphate with $\mathrm{pH}\left(87 \% \mathrm{HPO}_{4}{ }^{2-}\right.$ at $\mathrm{pH} 8.05$ and $48 \% \mathrm{HPO}_{4}{ }^{2-}$ at $\left.\mathrm{pH} 12.34\right)$ could account for the consistently higher rates at $\mathrm{pH} 8$ than $\mathrm{pH} 12$. Apparently the protonated phosphate ions are much stronger nucleophiles than the $\mathrm{PO}_{4}{ }^{3-}$ ion.

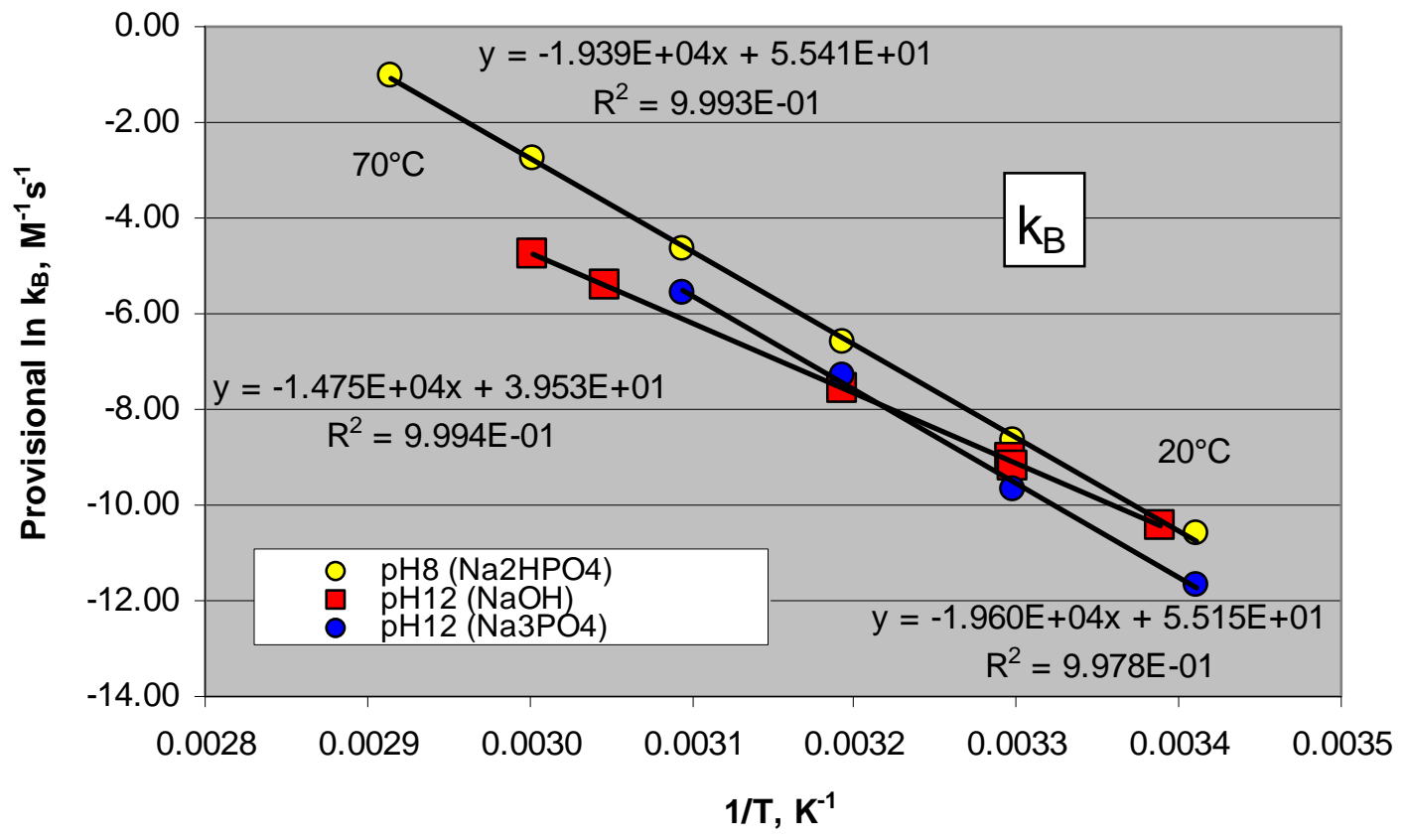

Figure 3.3. Arrhenius Plot of Base-Catalyzed Homogeneous Hydrolysis Data for Chloroform 
Because we are interested in the base-catalyzed rate constants, not the additional catalytic effect of phosphate, we will use the data collected in $\mathrm{NaOH}$ for further calculations. The good agreement between $\mathrm{NaOH}$ and $\mathrm{pH} 80.1-\mathrm{M}$ phosphate data at $20^{\circ} \mathrm{C}$ suggests that neither $\mathrm{HPO}_{4}{ }^{2-}$ nor $\mathrm{HCO}_{3}{ }^{-}$, which has roughly equivalent nucleophilicity (Schwarzenbach et al. 1993, p. 359) and is ubiquitous in groundwater, will impact the base-catalyzed reaction rate in groundwater significantly.

The activation energies for base-catalyzed CF hydrolysis are $123 \mathrm{KJ} \mathrm{mol}^{-1}$ for the $\mathrm{NaOH}$ experiments at $\mathrm{pH} 12,163 \mathrm{~kJ} \mathrm{~mol}^{-1}$ for the experiments in $0.1 \mathrm{~m}$ phosphate at $\mathrm{pH} 12$, and $161 \mathrm{~kJ} \mathrm{~mol}^{-1}$ for experiments in $0.1 \mathrm{~m}$ phosphate at $\mathrm{pH} 8$. These compare with a value of $105 \mathrm{~kJ} \mathrm{~mol}^{-1}$ reported from high-temperature experiments by Jeffers et al. (1989) using minimal headspace (about 2\%) ampules without correction for Henry's law.

The homogeneous hydrolysis data for $\mathrm{CF}$ hydrolysis show that two factors, temperature and $\mathrm{pH}$, have a strong bearing on the rate at which it degrades. With the Arrhenius' expressions for both $\mathrm{k}_{\mathrm{N}}$ and $\mathrm{k}_{\mathrm{B}}$ in hand, we can calculate overall rate constants and corresponding half-lives for any combination of temperature or $\mathrm{pH}$ within or near the range measured using

$$
-\mathrm{d}\left[\mathrm{CHCl}_{3}\right] / \mathrm{dt}=\left(\mathrm{k}_{\mathrm{N}}+\mathrm{k}_{\mathrm{B}}\left[\mathrm{OH}^{-}\right]\right)\left[\mathrm{CHCl}_{3}\right]
$$

A plot of data for temperatures between $10^{\circ} \mathrm{C}$ and $70^{\circ} \mathrm{C}$, and $\mathrm{pH}$ values between 5 and 10 is given in Fig. 3.4. For reference, the typical $\mathrm{pH}$ and temperature of Hanford groundwater are shown by the yellow datapoint, and the impact of temperature alone on hydrolysis half-life is given by the dashed yellow line. From this plot, we infer that either an increase in $\mathrm{pH}$ of about one unit or an increase in temperature of about $15^{\circ} \mathrm{C}$ will decrease the hydrolysis half-life of CF by an order of magnitude.

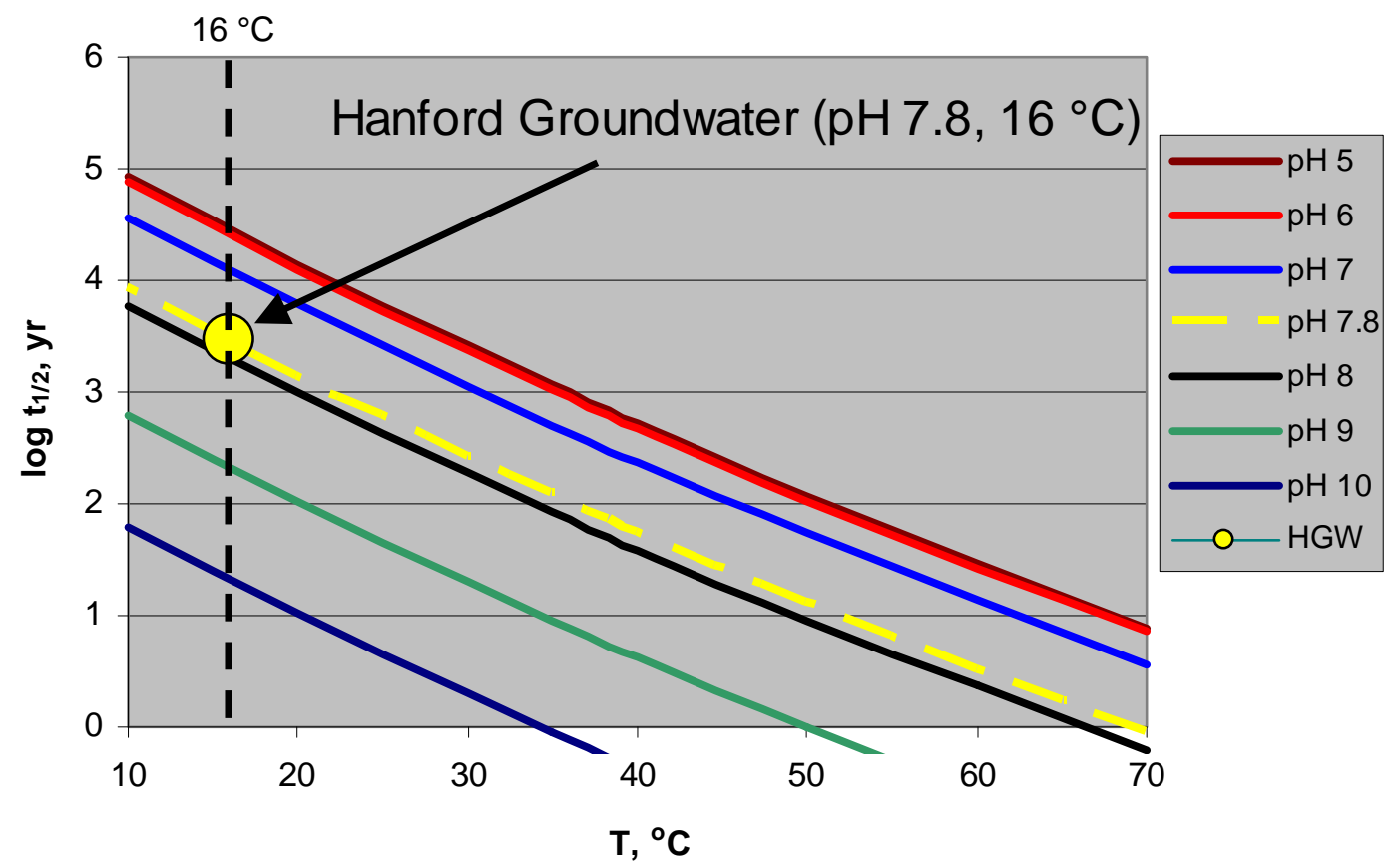

Figure 3.4. Impact of Temperature and $\mathrm{pH}$ on Hydrolysis Half-life Predicted for Chloroform From Homogeneous Rate Data Developed in This Project 


\subsection{Heterogeneous Experiments with Carbon Tetrachloride}

A total of six sets of experiments involving CT reacting in Hanford groundwater in the presence of a Hanford Site sediment or specific minerals are either underway or completed. The status of these experiments is given in Table 3.11. Because each experiment involves sampling at 10 separate time periods, the progress is given in terms of the number of sampling periods that have occurred (i.e., percentage of the initial ampules filled that have been terminated). Two of the experimental sets involve a Hanford Site sediment; one of these is complete, and the other is still in the early stages. Data from the completed set are given in Tables 3.12 and 3.13. An Arrhenius plot of these data together with homogeneous system data collected for deionized water and Hanford groundwater systems is shown in Figure 3.5. These data incorporate additional time points, as well as definitive values of initial CT concentrations stemming from analyses of control samples in FY 2010.

Table 3.11. Status of PNNL Heterogeneous Carbon Tetrachloride Hydrolysis Experiments in Hanford Groundwater

\begin{tabular}{|c|c|c|c|c|c|c|}
\hline & $\begin{array}{l}\text { Hanford } \\
\text { Sediment }\end{array}$ & $\begin{array}{c}\text { Hanford } \\
\text { Sediment, } \\
\text { FY } 2009\end{array}$ & $\begin{array}{l}\text { Montmorillon } \\
\text { ite }\end{array}$ & Kaolinite & Albite & Muscovite \\
\hline \multicolumn{7}{|l|}{$\begin{array}{l}\text { Temperature, } \\
{ }^{\circ} \mathrm{C}\end{array}$} \\
\hline 50 & 100 & $\sqrt{1+1}$ & 100 & 100 & 100 & 100 \\
\hline 40 & 100 & 20 & 100 & 100 & 100 & 100 \\
\hline 35 & $\sqrt{1+1}$ & 20 & $\sqrt{1+1}$ & $\sqrt{1+4}$ & $\sqrt{1+1}$ & $\sqrt{1+4}$ \\
\hline 30 & 90-completed & 30 & 90 & 90 & 90 & 80 \\
\hline 25 & $\sqrt{\mathrm{N}}$ & 20 & $\sqrt{1+1}$ & $\sqrt{1+\sqrt{n+1}}$ & $\sqrt{n+1}$ & $\sqrt{4}$ \\
\hline 20 & 60-completed & 30 & 70 & 70 & 70 & 70 \\
\hline
\end{tabular}

In contrast to our previous reports, the presence of Hanford Site sediment seems to have little effect on the rate of CT hydrolysis relative to that in homogeneous solution at temperatures of $30^{\circ} \mathrm{C}$ and higher. One data point, at $20^{\circ} \mathrm{C}$, suggests an heterogeneous effect that significantly $(\mathrm{p} \approx 0.05)$ increases the rate of CT hydrolysis above that in homogeneous solution. A single, marginally significant data point, however, cannot be considered definitive proof for the existence of such an effect. The new set of experiments started in FY2009 should clarify the situation once usable data become available.

Table 3.12. Provisional Rate Constants for Hydrolysis of Carbon Tetrachloride in Suspensions of Hanford Site Sediment in Hanford Groundwater

\begin{tabular}{lcccc}
\hline Temperature, ${ }^{\circ} \mathrm{C}$ & $\begin{array}{c}\text { Initial } \mathrm{CCl}_{4} \\
\text { Concentration, } \mathrm{mg} \mathrm{L}^{-1}\end{array}$ & $\mathrm{k}_{\mathrm{zhs}}$, PNNL, $\mathrm{s}^{-1}$ & $\mathrm{k}_{\text {app }}$, PNNL, $\mathrm{s}^{-1}$ & $\mathrm{~K}_{\mathrm{H}}{ }^{\prime}$, Gossett (1987) \\
\hline 50 & 371 & $1.24 \mathrm{e}-8$ & $4.55 \mathrm{e}-9$ & 3.562 \\
40 & 371 & $2.46 \mathrm{e}-9$ & $1.14 \mathrm{e}-9$ & 2.377 \\
30 & 371 & $4.70 \mathrm{e}-10$ & $2.68 \mathrm{e}-10$ & 1.543 \\
20 & 371 & $2.27 \mathrm{e}-10$ & $1.54 \mathrm{e}-10$ & 0.971 \\
\hline
\end{tabular}


Table 3.13. Provisional Half-Life Values for Hydrolysis of Carbon Tetrachloride in Suspensions of Hanford Site Sediment in Hanford Site Groundwater Based on Rate Constants in Table 3.11

\begin{tabular}{lcccc}
\hline Temperature, ${ }^{\circ} \mathrm{C}$ & $\begin{array}{c}\text { Initial CCl } \\
\text { Concentration, } \mathrm{mg} \mathrm{L}^{-1}\end{array}$ & $\begin{array}{c}\mathrm{t}_{1 / 2} \text { using } \mathrm{k}_{\text {zhs }}, \\
\text { PNNL, yr }\end{array}$ & $\begin{array}{c}\mathrm{t}_{1 / 2} \text { using } \mathrm{k}_{\text {app }}, \\
\text { PNNL, yr }\end{array}$ & K $_{\mathrm{H}^{\prime}}$, Gossett (1987) \\
\hline 50 & 371 & 1.8 & 4.8 & 3.562 \\
40 & 371 & 8.9 & 19. & 2.377 \\
30 & 371 & 47. & 82. & 1.543 \\
20 & 371 & 97. & 140. & 0.971 \\
\hline
\end{tabular}

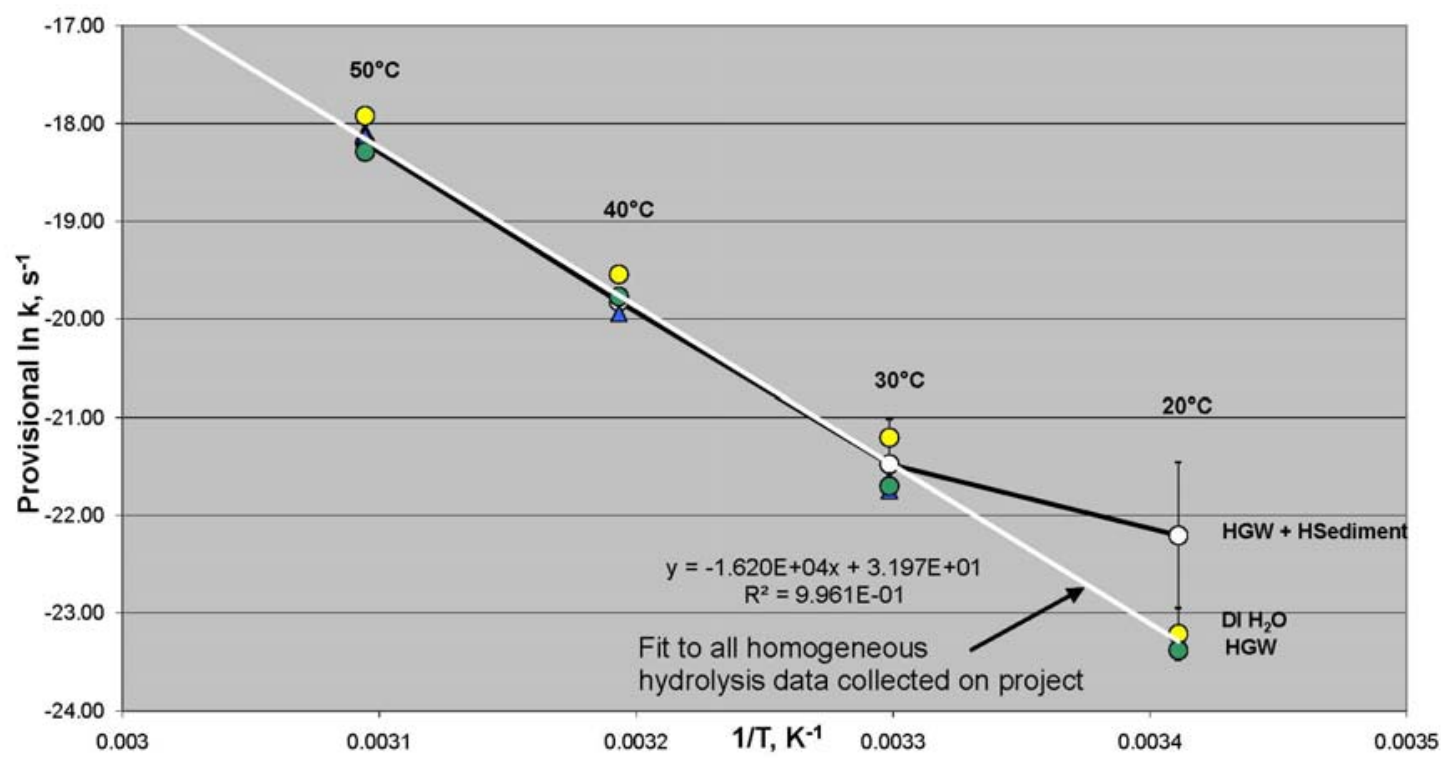

Figure 3.5. Arrhenius Plot of $\mathrm{k}_{\mathrm{zhs}}$ Data for Hydrolysis of Carbon Tetrachloride in Deionized Water, Hanford Groundwater, and Suspensions of Oxidized Hanford Sediment in Hanford Groundwater. Blue triangles are SUNY data for deionized water using zero-headspace reactors.

Another possible explanation of the $20^{\circ} \mathrm{C}$ result is that biotic activity, which would likely be optimized at temperatures close to the ambient groundwater temperature to which the microorganisms are acclimated, could have caused enhanced degradation of CT by processes other than hydrolysis. However, biotic activity would be expected to yield some CF as a product (Bouwer and McCarty 1983; Criddle et al. 1990b; Laine and Cheng 2007) except in pure cultures under denitrifying conditions (Criddle et al. 1990a; Tatara et al. 1993; Phanikumar et al. 2002). To assess whether biotic activity was responsible for the results with sediment, in FY 2008 we tested 16 samples from the hydrolysis treatments involving deionized water, Hanford Site groundwater, and the treatment with Hanford Site sediment for evidence of $\mathrm{CF}$ formation during the experiment. Chloroform hydrolyzes at a slower rate than $\mathrm{CT}$ at the near-neutral $\mathrm{pH}$ values of the experiment, and so a very slight increase in the CF-to-CT ratio (i.e., CF/CT) would be expected in samples where hydrolysis occurred relative to those where it did not (i.e., samples quenched at $4^{\circ} \mathrm{C}$ ). On the other hand, if biotic activity were responsible for CT degradation, a large increase in $\mathrm{CF} / \mathrm{CT}$ would be expected from generation of $\mathrm{CF}$ as product of the biotic degradation reaction. In 
general, the results of these analyses showed no significant difference in $\mathrm{CF} / \mathrm{CT}$ between samples that showed loss of CT (presumably from hydrolysis) and those showing no loss. There were two exceptions, both for $40^{\circ} \mathrm{C}$ samples (one in Hanford Site groundwater and the other involving Hanford Site sediment) that may have been contaminated during preparation. We conclude therefore that the possible enhancement of hydrolysis rates due to the presence of sediment does not stem from biotic activity.

The remaining heterogeneous experiments with $\mathrm{CT}$ involve four minerals representative of the Hanford Site as pure phases. Three heterogeneous hydrolysis experiments were started in FY 2007 and the remaining one in early in FY 2008. All the experiments involve suspensions of minerals in Hanford groundwater. The data collected to date allow us to calculate provisional rate constants for heterogeneous hydrolysis of $\mathrm{CT}$ at $50^{\circ} \mathrm{C}, 40^{\circ} \mathrm{C}$, and $30^{\circ} \mathrm{C}$ (Table 3.14 ).

The results continue to show little if any difference in the rates of CT hydrolysis among the four minerals tested. When compared to rates measured in homogeneous solution (Hanford groundwater) and for Hanford sediment in Hanford groundwater obtained in the Hanford Groundwater Project study ${ }^{1}$, these mineral-specific rates tend to be similar or slightly slower. As that project has demonstrated, however, the primary influence of heterogeneous surfaces on CT hydrolysis rates manifests itself, if at all, at temperatures below $30^{\circ} \mathrm{C}$. Completion of the experiments at lower temperatures, therefore, is needed before any conclusions can be drawn about the possible influence of these specific mineral phases on CT hydrolysis rates.

Table 3.14. Provisional Rate Constants for Hydrolysis of Carbon Tetrachloride in Suspensions of Minerals in Hanford Groundwater

\begin{tabular}{lccccc}
\hline Mineral Phase & Temperature, ${ }^{\circ} \mathrm{C}$ & $\begin{array}{c}\text { Initial CCl }{ }_{4} \text { Concentration, } \\
\mathrm{mg} \mathrm{L}^{-1}\end{array}$ & $\begin{array}{c}\mathrm{k}_{\text {zhs }} \\
\text { PNNL, s }\end{array}$ & $\begin{array}{c}\mathrm{k}_{\text {app }} \\
\text { PNNL, s }\end{array}$ & $\begin{array}{c}\mathrm{K}_{\mathrm{H}^{\prime}}\left(\mathrm{Gossett}^{1}\right. \\
1987)\end{array}$ \\
\hline Muscovite & 50 & 311 & $9.94 \mathrm{e}-09$ & $3.63 \mathrm{e}-09$ & 3.562 \\
Kaolinite & 50 & 368 & $9.92 \mathrm{e}-09$ & $3.62 \mathrm{e}-09$ & 3.562 \\
Albite & 50 & 375 & $9.71 \mathrm{e}-09$ & $3.55 \mathrm{e}-9$ & 3.562 \\
Montmorillonite & 50 & 410 & $9.76 \mathrm{e}-09$ & $3.57 \mathrm{e}-09$ & 3.562 \\
Muscovite & 40 & 311 & $2.13 \mathrm{e}-09$ & $9.86 \mathrm{e}-10$ & 2.377 \\
Kaolinite & 40 & 368 & $2.07 \mathrm{e}-09$ & $9.57 \mathrm{e}-10$ & 2.377 \\
Albite & 40 & 375 & $2.07 \mathrm{e}-09$ & $9.59 \mathrm{e}-10$ & 2.377 \\
Montmorillonite & 40 & 410 & $2.15 \mathrm{e}-09$ & $9.98 \mathrm{e}-10$ & 2.377 \\
Muscovite & 30 & 311 & $3.65 \mathrm{e}-10$ & $2.08 \mathrm{e}-10$ & 1.543 \\
Kaolinite & 30 & 368 & $2.59 \mathrm{e}-10$ & $1.48 \mathrm{e}-10$ & 1.543 \\
Albite & 30 & 375 & $3.15 \mathrm{e}-10$ & $1.80 \mathrm{e}-10$ & 1.543 \\
Montmorillonite & 30 & 410 & $3.52 \mathrm{e}-10$ & $2.01 \mathrm{e}-10$ & 1.543 \\
\hline
\end{tabular}

\footnotetext{
${ }^{1}$ Amonette JE, PM Jeffers, O Qafoku, CK Russell, TW Wietsma, and MJ Truex. Abiotic Degradation Rates for Carbon Tetrachloride: Progress in FY 2008. 2008 Draft Report, Pacific Northwest National Laboratory, Richland, Washington.
} 


\subsection{Heterogeneous Experiments with Chloroform}

The status of the heterogeneous experiments with CF is summarized in Tables 3.15 and 3.16. Five experimental sets were started in FY 2007 and early FY 2008; two additional experimental sets involving careful control of $\mathrm{pH}$ were started in late FY 2009. All the experiments involve suspensions of minerals or Hanford sediment in Hanford groundwater. Because each experiment involves sampling at 10 separate time periods, the progress is given in terms of the number of sampling periods that have occurred (i.e., percentage of the initial ampules filled that have been terminated). Provisional zero-headspace rate constants for heterogeneous hydrolysis of CF are given in Table 3.17 for the experiments where sufficient data have been collected. These rate constants are "pseudo-first-order" rate constants, $\mathrm{k}_{\mathrm{pfo}}$, where

$$
\mathrm{k}_{\mathrm{pfo}}=\mathrm{k}_{\mathrm{N}}+\mathrm{k}_{\mathrm{B}}\left[\mathrm{OH}^{-}\right]
$$

In stark contrast to the mineral-specific rates obtained for $\mathrm{CT}$, the pseudo-first-order heterogeneous hydrolysis rates obtained for $\mathrm{CF}$ at $50^{\circ} \mathrm{C}$ vary by a factor of 18 . This result likely stems in part from different $\mathrm{pH}$ values maintained by these minerals in contact with Hanford groundwater. To test this premise, we measured the $\mathrm{pH}$ of suspensions of these minerals and Hanford sediment in Hanford groundwater, which had a $\mathrm{pH}$ of 8.60 (this $\mathrm{pH}$ is about 0.85 unit higher than that recorded in the field, presumably due to degassing of $\mathrm{CO}_{2}$ from the sample during storage). For most minerals and the Hanford sediment, the $\mathrm{pH}$ dropped by 0.1 to 0.25 unit, and there was no correlation between the $\mathrm{pH}$ decrease and the difference between the rate constant and that obtained in homogeneous solution. For the montmorillonite, however, a full $\mathrm{pH}$ drop of 0.8 unit was recorded, and this mineral also yielded the largest decrease in hydrolysis rate.

Table 3.15. Status of PNNL Heterogeneous Chloroform Hydrolysis Experiments in Hanford Groundwater Started in FY 2007 and FY 2008.

\begin{tabular}{|c|c|c|c|c|c|}
\hline & Hanford Sediment & Montmorillonite & Kaolinite & Albite & Muscovite \\
\hline Temperature, ${ }^{\circ} \mathrm{C}$ & \multicolumn{5}{|c|}{----------- Percentage of experiment sampled as of 30 September 2010 ----------- } \\
\hline 50 & 80-completed & 100 & 100 & 90-completed & 100 \\
\hline 40 & 70-completed & 70 & 50 & 50 & 50 \\
\hline 30 & 50-completed & 50 & 40 & 40 & 40 \\
\hline 20 & 60 & 50 & 40 & 40 & 40 \\
\hline
\end{tabular}

Table 3.16. Status of PNNL Heterogeneous Chloroform Hydrolysis Experiments at $\mathrm{pH} 7.2$ in Hanford Groundwater Started in FY 2009.

\begin{tabular}{lcc}
\cline { 2 - 3 } & $\begin{array}{c}\text { Hanford Sediment, } \\
\text { FY 2009 }\end{array}$ & $\begin{array}{c}\text { Montmorillonite, } \\
\text { FY 2009 }\end{array}$ \\
\hline Temperature, ${ }^{\circ} \mathrm{C}$ & $\begin{array}{c}\text { Percentage of experiment sampled as } \\
\text { of 30 September 2010 }\end{array}$ \\
\hline 40 & 20 & 20 \\
35 & 20 & 20 \\
30 & 30 & 30 \\
25 & 20 & 20 \\
20 & 30 & 30 \\
\hline
\end{tabular}


Table 3.17. Provisional Pseudo-First-Order Rate Constants for Hydrolysis of Chloroform in Suspensions of Hanford Sediment or Specific Minerals in Hanford Groundwater

\begin{tabular}{lccccc}
\hline Solid Phase & Temperature, ${ }^{\circ} \mathrm{C}$ & $\begin{array}{c}\text { Initial CHCl } \\
\text { Concentration, } \mathrm{mg} \mathrm{L}^{-1}\end{array}$ & $\begin{array}{c}\mathrm{k}_{\mathrm{zhs}} \text { PNNL, } \\
\mathrm{s}^{-1}\end{array}$ & $\begin{array}{c}\mathrm{k}_{\text {app }} \text { PNNL, } \\
\mathrm{s}^{-1}\end{array}$ & $\begin{array}{c}\mathrm{K}_{\mathrm{H}^{\prime}} \text { (Gorgenyi } \\
\text { et al. 2002) }\end{array}$ \\
\hline Hanford Sediment & 50 & 476 & $3.02 \mathrm{e}-09$ & $2.51 \mathrm{e}-09$ & 0.417 \\
Muscovite & 50 & 473 & $2.79 \mathrm{e}-09$ & $2.32 \mathrm{e}-09$ & 0.417 \\
Kaolinite & 50 & 495 & $1.46 \mathrm{e}-09$ & $1.21 \mathrm{e}-09$ & 0.417 \\
Albite & 50 & 424 & $1.77 \mathrm{e}-09$ & $1.47 \mathrm{e}-09$ & 0.417 \\
Montmorillonite & 50 & 389 & $1.72 \mathrm{e}-10$ & $1.43 \mathrm{e}-10$ & 0.417 \\
Hanford Sediment & 40 & 476 & $6.56 \mathrm{e}-10$ & $5.73 \mathrm{e}-10$ & 0.296 \\
Muscovite & 40 & 473 & $4.70 \mathrm{e}-10$ & $4.10 \mathrm{e}-10$ & 0.296 \\
Kaolinite & 40 & 495 & $2.06 \mathrm{e}-10$ & $1.80 \mathrm{e}-10$ & 0.296 \\
Albite & 40 & 424 & $1.63 \mathrm{e}-10$ & $1.43 \mathrm{e}-10$ & 0.296 \\
Hanford Sediment & 30 & 476 & $3.80 \mathrm{e}-11$ & $3.44 \mathrm{e}-11$ & 0.209 \\
Muscovite & 30 & 473 & $8.32 \mathrm{e}-11$ & $7.55 \mathrm{e}-11$ & 0.209 \\
Hanford Sediment & 20 & 476 & $2.13 \mathrm{e}-11$ & $2.00 \mathrm{e}-11$ & 0.137 \\
\hline
\end{tabular}

The range in pseudo-first-order rate constants obtained at $50^{\circ} \mathrm{C}$ for the minerals and Hanford sediment, together with values calculated from Arrhenius data for several homogeneous solutions having different $\mathrm{pH}$ is shown in Figure 3.4. The expected trend with $\mathrm{pH}$ in homogeneous solution is shown, noting that $\mathrm{pH} 8.6$ is the $\mathrm{pH}$ of Hanford groundwater after prolonged storage at atmospheric levels of $\mathrm{CO}_{2}$, whereas $\mathrm{pH} 7.75$ is the actual $\mathrm{pH}$ of the groundwater before degassing. The main concept shown in Figure 3.4, however, is simply that the solid phases seem to act as significant $\mathrm{pH}$ buffers to yield CF hydrolysis rates expected for solutions that are more acidic than the groundwater. The effect is particularly striking with the montmorillonite clay, which yields pseudo-first-order rate constants similar to those obtained at $\mathrm{pH} 3$ in homogeneous solution. To clarify whether the impact of the minerals is due solely to $\mathrm{pH}$, two new sets of experiments were prepared in FY 2009 for incubation in the same temperature range as the new CT experiment with Hanford sediment. These experiments involved equilibrating the montmorillonite or Hanford sediment in Hanford groundwater at $\mathrm{pH} 7.2$ before contacting them with CF. This equilibration took several weeks before a constant $\mathrm{pH}$ was obtained. 


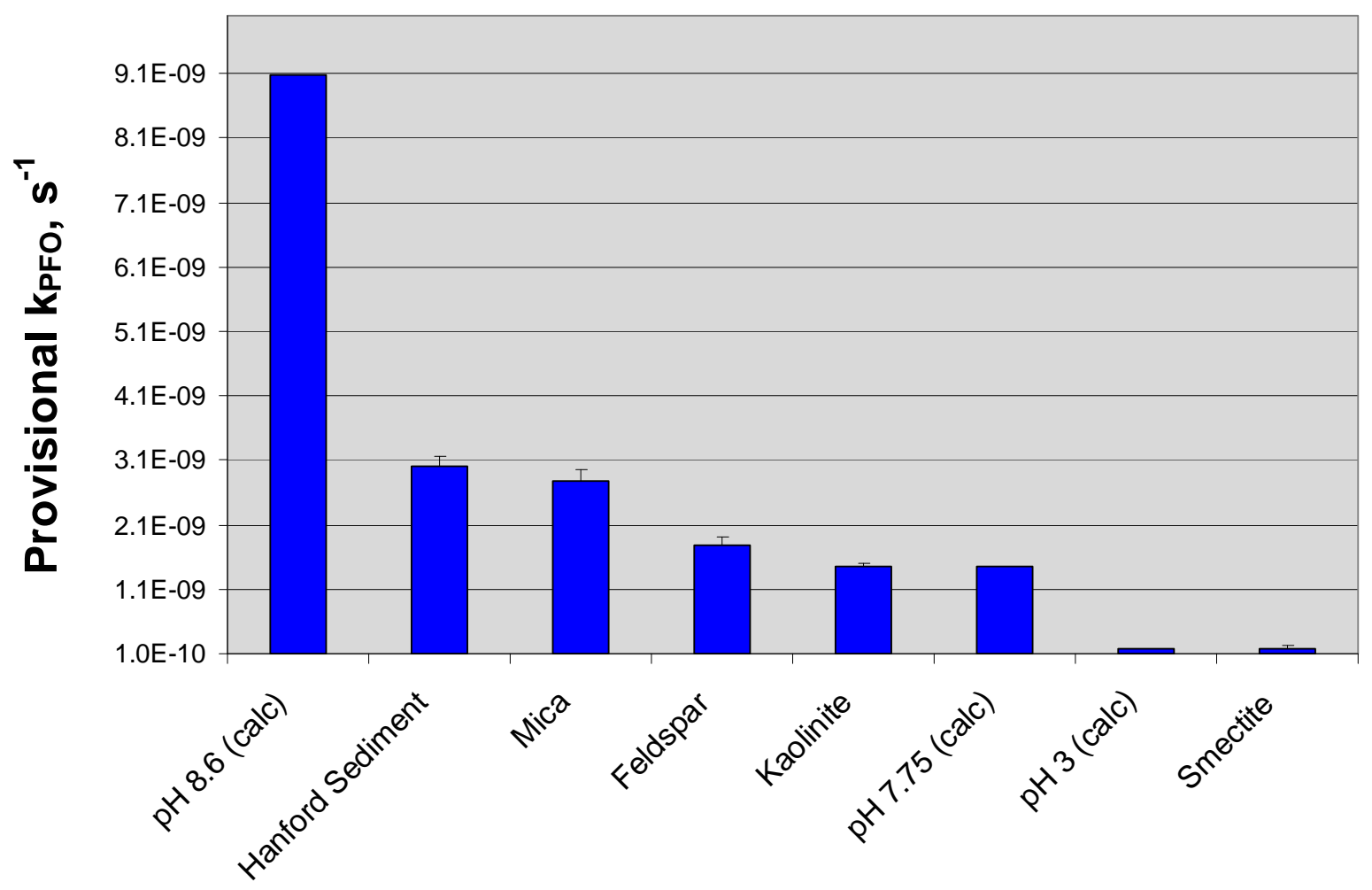

Figure 3.6. Provisional $\mathrm{k}_{\mathrm{PFO}}$ Data at $50^{\circ} \mathrm{C}$ for Hydrolysis of Chloroform in Suspensions of Minerals or Hanford Sediment and Calculated for Homogeneous Solutions at Several pH Levels 


\subsection{Liquid-Vapor Partition Coefficients}

As discussed in Section 3, CT rate constants derived from ZHR experiments at SUNY-Cortland were slightly, but consistently, lower than the $\mathrm{k}_{\text {zhr }}$ values from sealed vial experiments performed at PNNL. The PNNL calculations used Henry's law constants $\left(\mathrm{K}_{\mathrm{H}}{ }^{\prime}\right)$ for $\mathrm{CT}$ derived from a temperature fit of experimental values (Gossett 1987) but extrapolated considerably beyond the temperature range of his experiments to correct the apparent rate constant to values of $\mathrm{k}_{\mathrm{zhs}}$. Recognizing that Henry's law is strictly valid only at infinite dilution and ambient pressure, direct measurements of liquid-vapor partition coefficients $\left(\mathrm{K}_{\mathrm{lv}}\right)$ for both $\mathrm{CT}$ and $\mathrm{CF}$ at the concentrations used in our experiments were conducted at SUNY-Cortland and at PNNL in an attempt to provide experimental values valid at the temperatures of our joint experiments.

The SUNY-Cortland measurement protocol was described in Amonette et al. (2009), and involved measurement of CT and CF concentrations in the liquid phase before and after equilibration with a known volume of air in a specially designed reactor bulb. At PNNL, we developed an infrared spectroscopic method to measure the concentrations in the vapor phase (both CT and CF give strong absorptions in the mid-infrared part of the spectrum). We purchased an ultra-low-volume $0.5-\mathrm{m}$ path length gas cell (Fig. 4.1) with a nominal sample volume of $25 \mathrm{ml}$. This cell required a minimum of about $35 \mathrm{ml}$ of gas to totally flush the cell with a new sample.

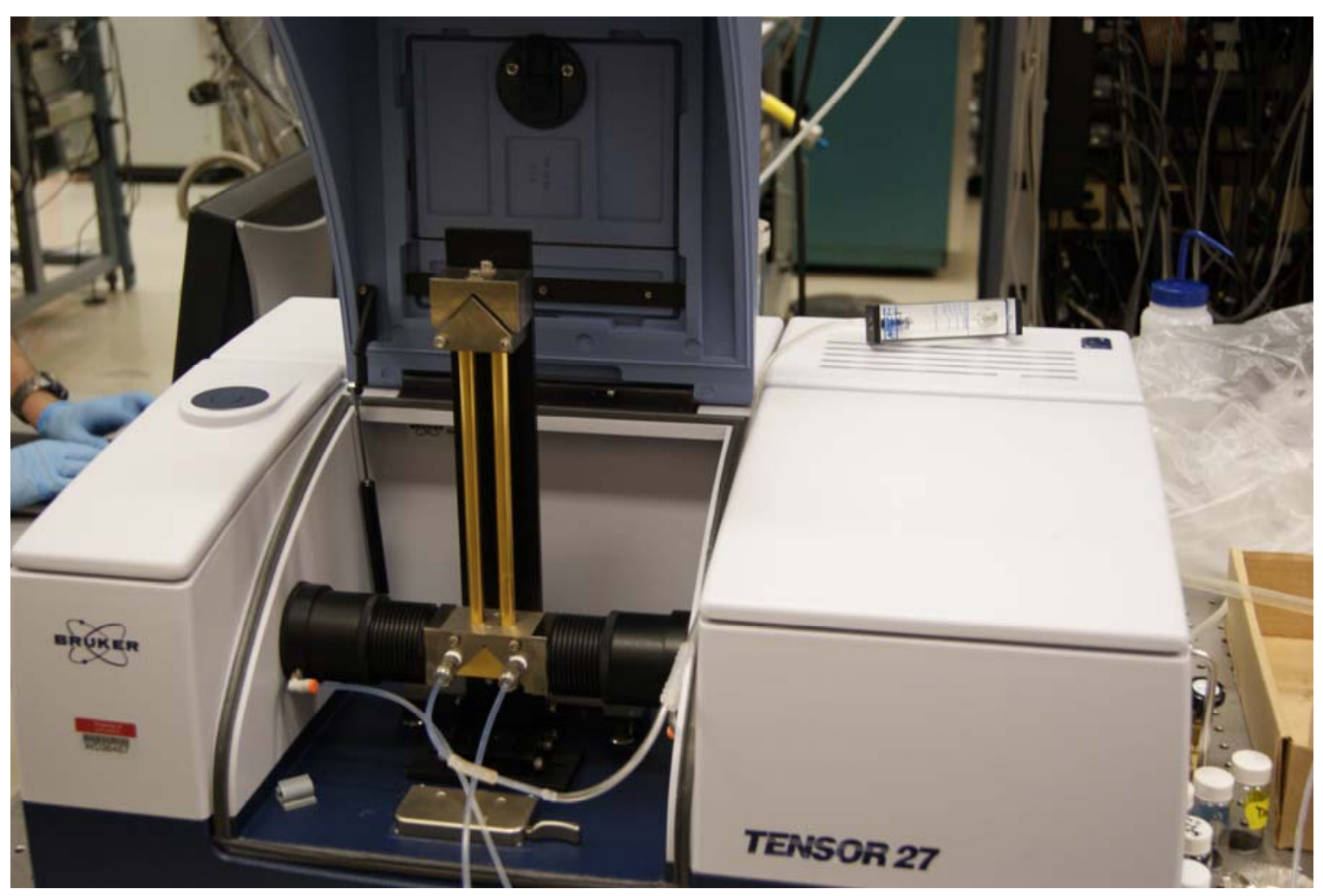

Figure 4.1. Infrared Gas Cell and Spectrometer Used in the Liquid-Vapor Partition Coefficient Determinations at PNNL 
In a typical experiment, which was adapted from that of McAuliffe (1971) as described in Schwarzenbach et al. (1993, p. 118-119), we equilibrated $50 \mathrm{ml}$ of liquid (containing either CT or CF) in a $100-\mathrm{ml}$ gas syringe with $50 \mathrm{ml}$ of headspace at a fixed temperature. The exact volumes of the liquid and headspace were determined gravimetrically. Temperature was maintained by an incubating shaker cabinet, and the syringe was fixed in a special holder so that it could be spun at $200 \mathrm{rpm}$ to induce adequate mixing between the liquid and the vapor in the syringe. Incubation period for each equilibration was ten minutes, as determined by preliminary experiments. At the end of the equilibration period, the headspace in the syringe was transferred to another gas syringe, which was securely capped and allowed to cool to room temperature. Fresh headspace was then added to the first syringe and a new equilibration period started. Once the sample in the second syringe had reached ambient temperature the gas was injected into the gas cell in the spectrometer. A spectrum was obtained in about 5 minutes.

An experiment consisted of several (at least 4) successive equilibrations, with the concentration of CT or CF in the vapor decreasing each time (Fig. 4.2). A plot of the log of the concentration versus equilibration number yielded a straight line (Fig. 4.3), the slope of which is used, together with the volumes of liquid and gas in the syringe, to calculate the partition coefficient $\left(\mathrm{K}_{\mathrm{lv}}\right)$ by

$$
\mathrm{K}_{\mathrm{lv}}=\left(10^{-\mathrm{m}}-1\right)\left(\mathrm{V}_{\mathrm{l}} / \mathrm{V}_{\mathrm{v}}\right)
$$

where $\mathrm{m}$ is the slope, $\mathrm{V}_{1}$ the volume of liquid and $\mathrm{V}_{\mathrm{v}}$ the headspace volume. For each experiment, we estimated concentration by the height of the absorption peak and by the area of the absorption peak. The two values thus obtained were then averaged, along with values from identical experiments, to obtain an estimate of the partition coefficient.

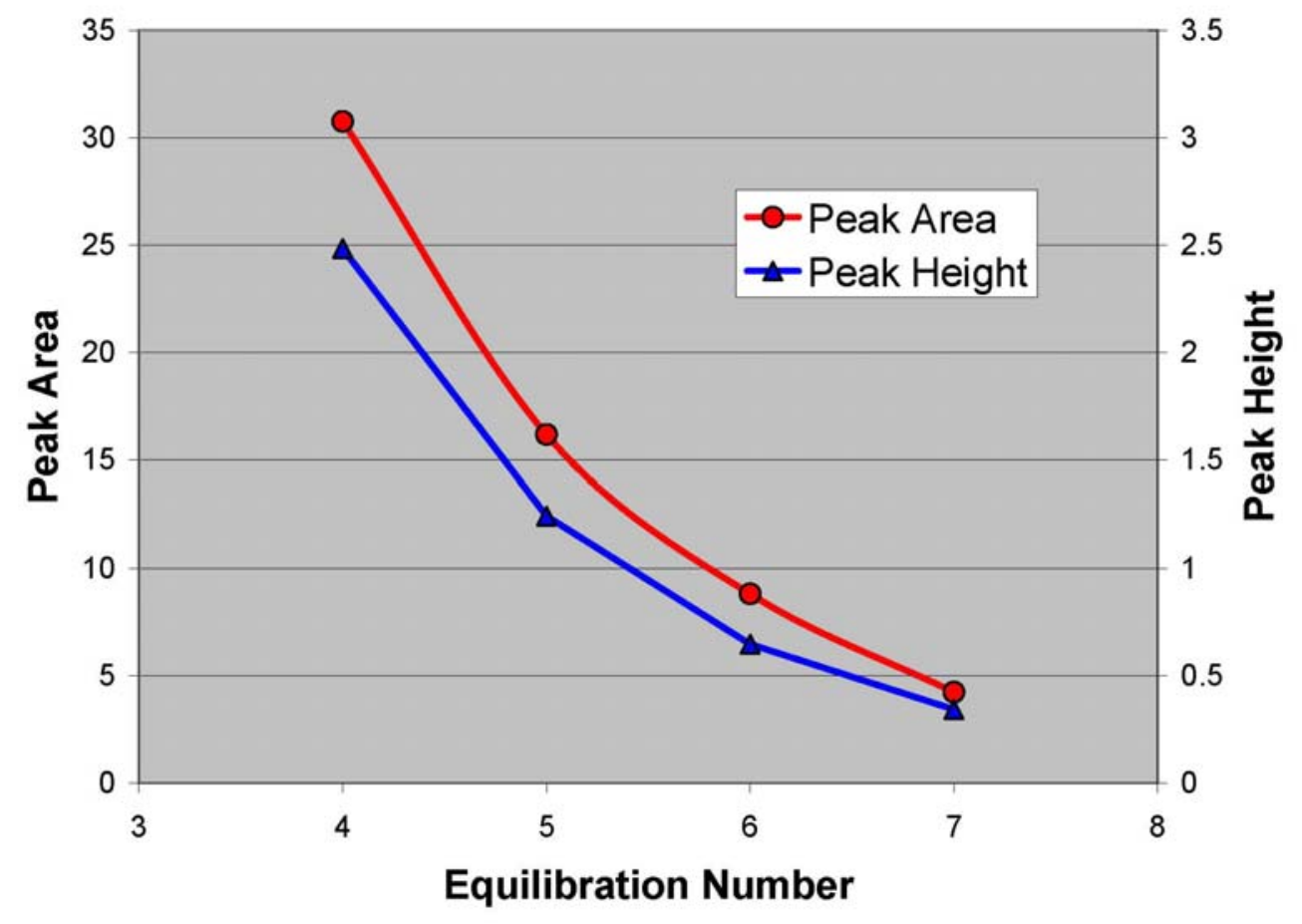

Figure 4.2. Plot of Typical Absorbance Data for Successive Equilibrations of CT in the Partition Coefficient Determination 


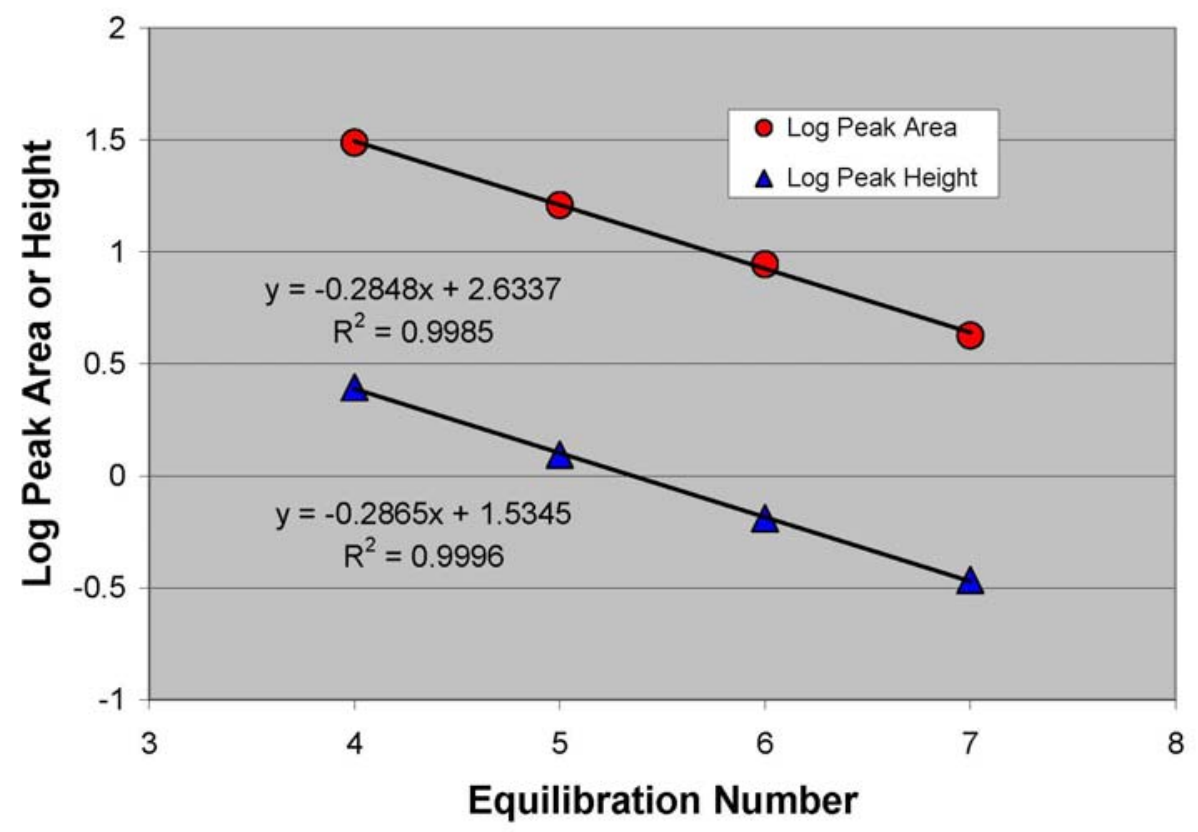

Figure 4.3. Linear Relation Between Log of Absorbance and Equilibration Number

The results of the $\mathrm{K}_{\mathrm{lv}}$ measurements for $\mathrm{CT}$ are shown in Figure 4.4, along with the data (measured and extrapolated) of Gossett (1987), values calculated using an equation derived by Staudinger and Roberts (2001) from a critical review of nine studies including Gossett (1987), and back-calculated values from the PNNL hydrolysis determinations in deionized water. These back calculations were done by assuming that the $\mathrm{k}_{\mathrm{zhs}}$ value obtained at SUNY-Cortland was correct, and the value of $\mathrm{K}_{\mathrm{H}}{ }^{\prime}$ used in the PNNL data calculations was varied until the PNNL $\mathrm{k}_{\mathrm{zhs}}$ value matched that of SUNY-Cortland.

The $\mathrm{K}_{\mathrm{lv}}$ results obtained by SUNY and PNNL are in excellent agreement, which is remarkable given that the measurements were made by entirely different methods, one focused on solution-phase data and the other on vapor-phase data (Fig. 4.4). The published values from the literature (Gossett, 1987; Staudinger and Roberts, 2001) also are in excellent agreement with each other. However, although the published data and those collected in this study agree well at near ambient temperatures, they diverge significantly at temperatures above $30^{\circ} \mathrm{C}$, differing by more than a factor of 2 at the highest temperatures. The backcalculated values from the PNNL hydrolysis-rate experiments differ significantly from both the published and measured values, being about a factor of 2 higher than the published values.

Given the seemingly robust nature of both the published values and those measured on this project, and the importance of $\mathrm{K}_{\mathrm{lv}}$ in calculating the $\mathrm{k}_{\mathrm{zhs}}$ values for the majority of our experimental data, we have devoted a significant effort to try to reconcile them. To date, the main thrust of this effort has focused on identifying a factor derived from relevant physical parameters that can be used to normalize the two sets of data. One such factor, here termed $\Psi_{\mathrm{x}}$, is

$$
\Psi_{\mathrm{x}}=\left(\mathrm{P}_{\mathrm{x}} \mathrm{T}_{\mathrm{ref}}\right) /\left(\mathrm{P}_{\mathrm{ref}} \mathrm{T}_{\mathrm{x}}\right)
$$

where $\mathrm{P}$ and $\mathrm{T}$ are the vapor pressure and temperature, respectively, and the subscripts " $\mathrm{x}$ " and "ref", indicate values for the temperature of interest (x) and a reference temperature (e.g., $20^{\circ} \mathrm{C}$ ). As shown in Figure 4.5, when our measured $\mathrm{K}_{\mathrm{lv}}$ values are multiplied by the appropriate values of $\Psi_{\mathrm{x}}$ (or the published 


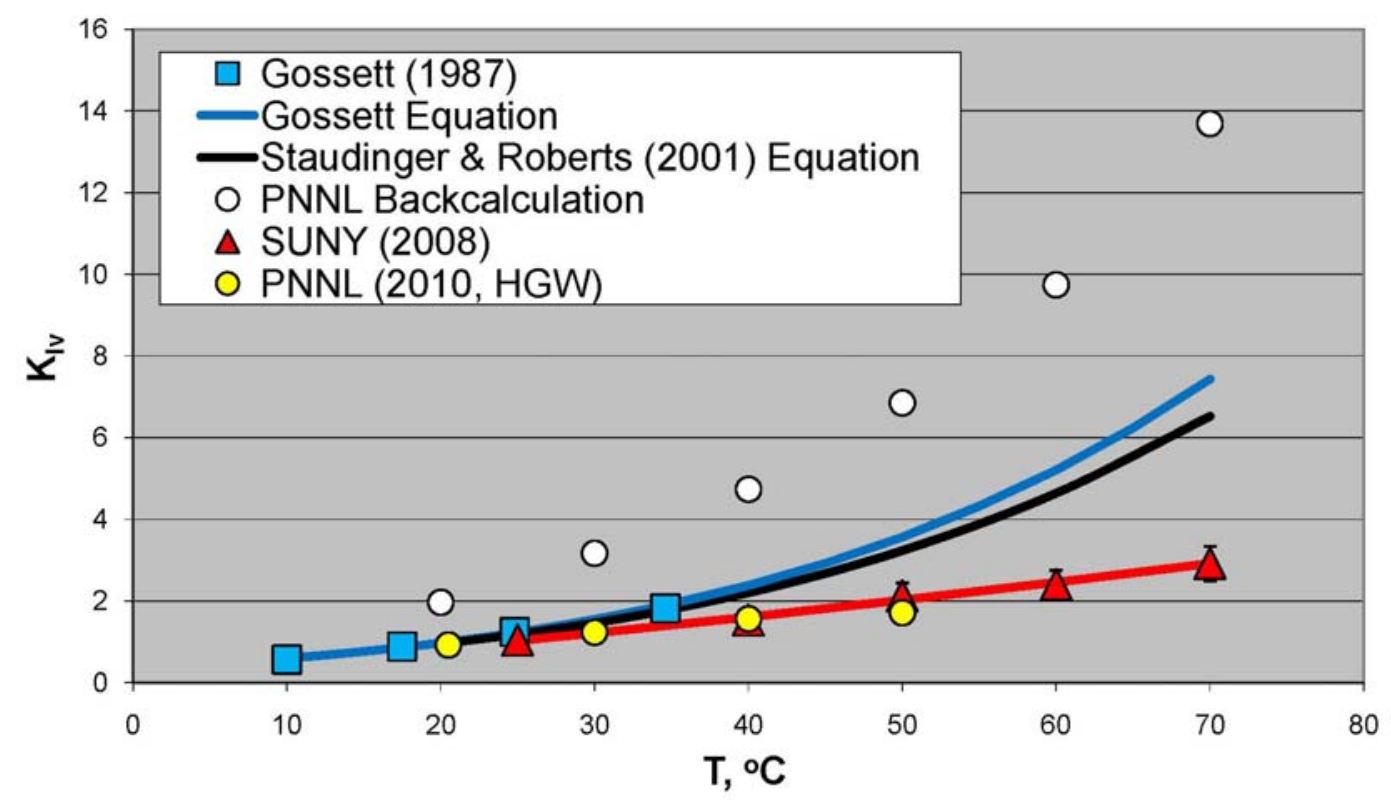

Figure 4.4. Values of $\mathrm{K}_{\mathrm{H}^{\prime}}$ Determined and Extrapolated to Higher Temperatures from Gossett (1987) and Staudinger \& Roberts (2001), Together with Direct Determinations of $\mathrm{K}_{\mathrm{lv}}$ at SUNY-

Cortland and PNNL, and Back-Calculated Values of $\mathrm{K}_{\mathrm{lv}}$ Derived from PNNL HydrolysisRate Determinations in Deionized Water

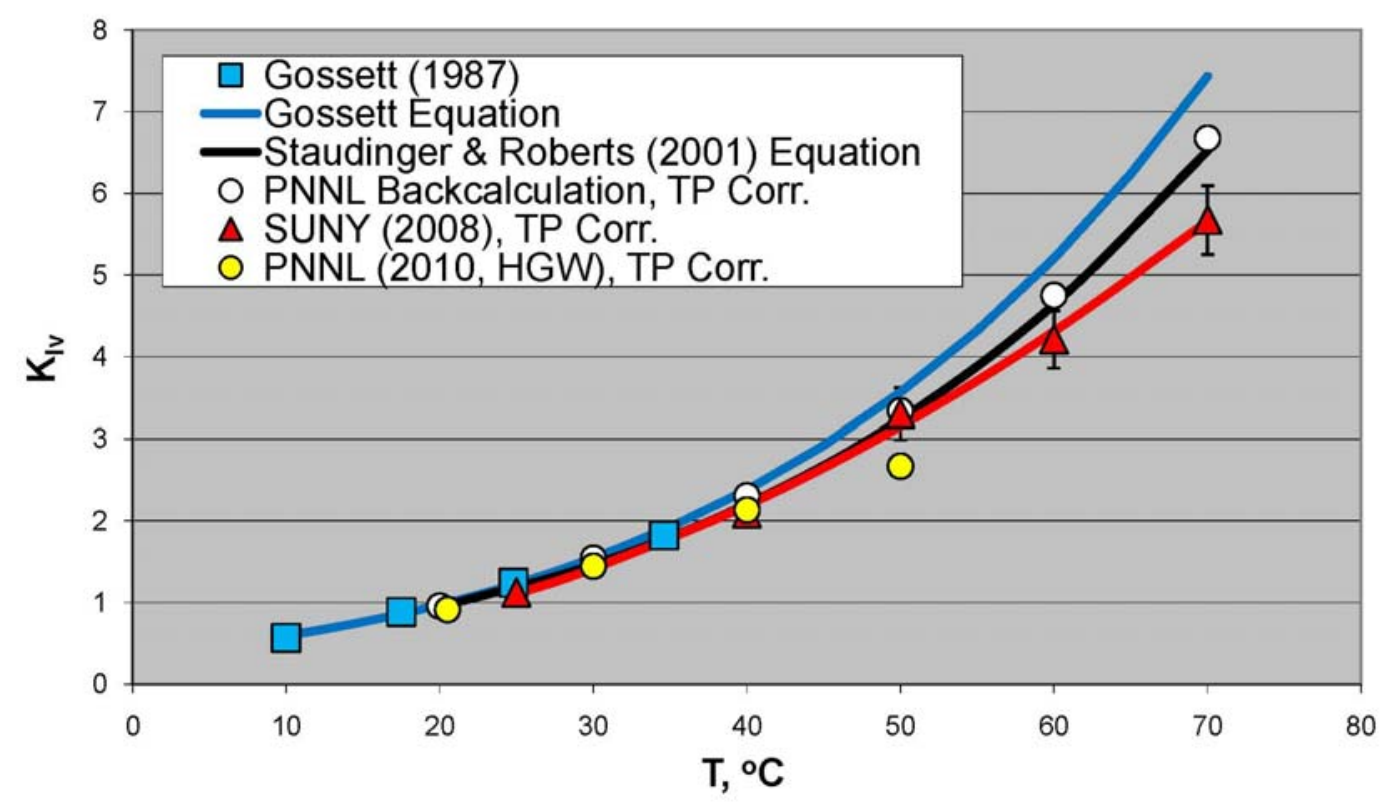

Figure 4.5. $\Psi_{\mathrm{x}}$-Normalized Values of $\mathrm{K}_{\mathrm{H}^{\prime}}$ Determined and Extrapolated to Higher Temperatures from Gossett (1987) and Staudinger \& Roberts (2001), Together with Direct Determinations of $\mathrm{K}_{\mathrm{lv}}$ at SUNY-Cortland and PNNL, and Back-Calculated Values of $\mathrm{K}_{\mathrm{lv}}$ Derived from PNNL Hydrolysis-Rate Determinations in Deionized Water 
values are divided by $\Psi_{\mathrm{x}}$ ), they converge nearly perfectly with the predicted values of Staudinger and Roberts (2001). Similarly, dividing our backcalculated $\mathrm{K}_{\mathrm{lv}}$ values by $\Psi_{\mathrm{x}}$ yields convergence (Fig. 4.5). In effect, $\Psi_{\mathrm{x}}$ corrects the concentration portion of $\mathrm{K}_{\mathrm{lv}}$ for changes in pressure associated with temperature, based on the ideal gas law.

Despite this convergence, we are not convinced that $\Psi_{\mathrm{x}}$ represents a rational solution to the problem, given that vapor pressure is a key portion of the Henry's Law relation. We note, however, that in at least one other study (Heron et al., 1998) steps were taken to decrease total pressure inside the headspace to near ambient levels before measuring the partition coefficient whereas, in our rate experiments and $\mathrm{K}_{\mathrm{lv}}$ measurements, autogenous pressures are maintained. We remain skeptical and will continue to examine the methodology and calculations used in our and other studies to try and reconcile the results.

A similar situation exists for $\mathrm{CF}$, although the size of the correction factor is much less. A total of 32 separate measurements were made at SUNY that sampled essentially the entire range of temperatures and concentrations of our CF hydrolysis rate experiments. In FY 2010, three measurements were made at PNNL at $20.5^{\circ} \mathrm{C}$ in deionized water, Hanford groundwater, and Hanford sediment suspended in Hanford groundwater. The PNNL results were identical (+/- 0.001) for all three systems, and exactly matched the value of 0.139 calculated by the Gorgenyi equation. The mean values obtained for $\mathrm{K}_{\mathrm{lv}}$ are shown in Figure 4.6, together with values for $\mathrm{K}_{\mathrm{h}}$ (measured and extrapolated) of Gorgenyi et al. (2002) and predicted values from Staudinger and Roberts (2001).

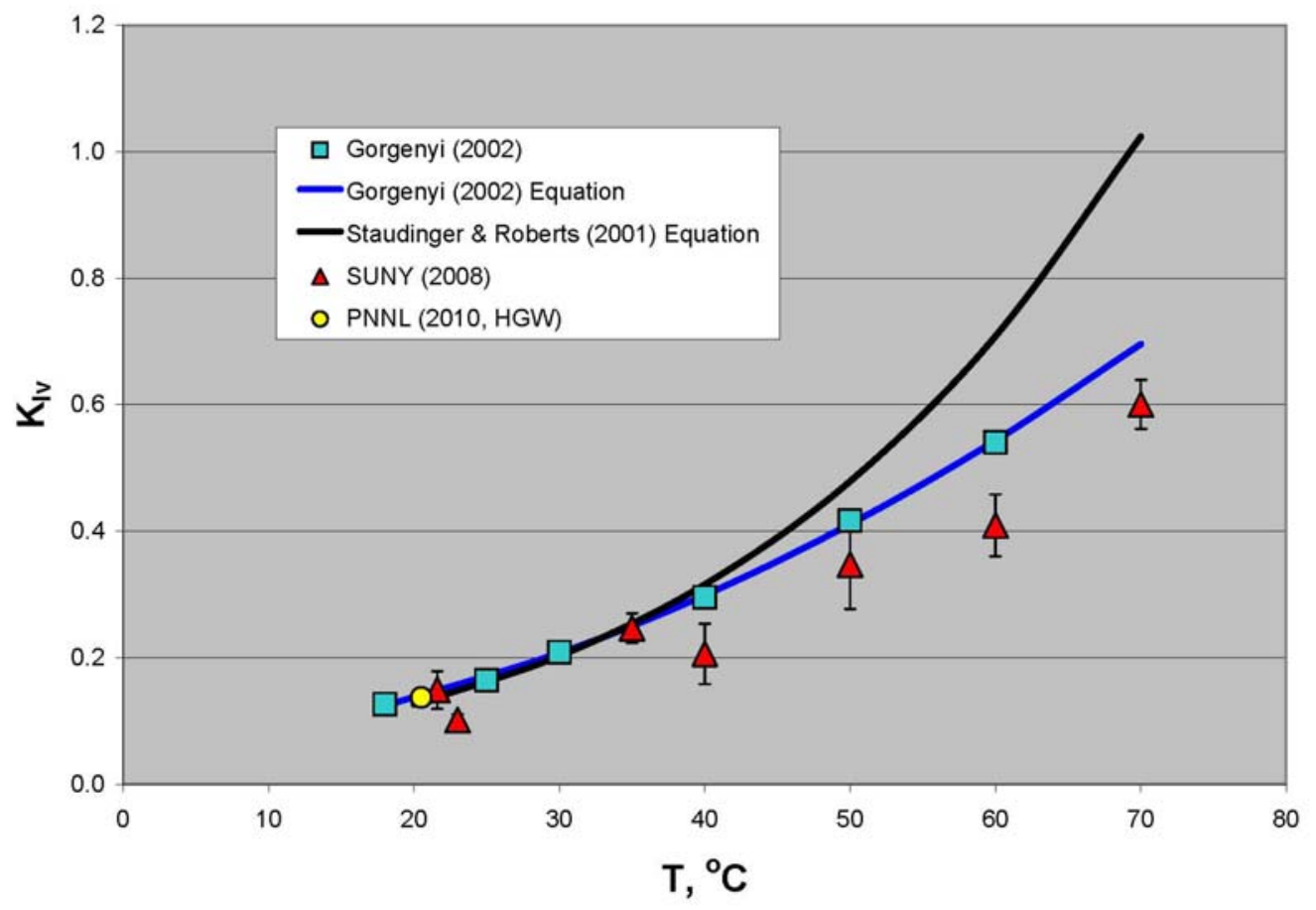

Figure 4.6. Mean Values of $\mathrm{K}_{\mathrm{lv}}$ for Chloroform Measured by SUNY-Cortland and PNNL, Together with $\mathrm{K}_{\mathrm{h}}$ Values for Chloroform Reported by Gorgenyi et al. (2002) and Predicted by Staudinger \& Roberts (2001)

Clearly, the $K_{1 v}$ results we have obtained and the $K_{h}$ values of Gorgenyi et al. (2002) and Staudinger and Roberts (2001) differ at temperatures above about $35^{\circ} \mathrm{C}$. As with CT, a more detailed analysis of the 
factors contributing to the differences is needed to identify the best way to correct our experimental rate constants for effects of liquid-vapor partitioning. As noted in Amonette et al. (2009), one of the possible reasons for the discrepancies with both $\mathrm{CT}$ and $\mathrm{CF} \mathrm{K}_{\mathrm{lv}}$ values could be the lack a valved tip on the syringes used in the PNNL measurements. We will conduct confirmatory experiments with a valved syringe in FY 2011 to provide better statistics and help us make a decision as to which set of partition coefficients to use in our corrections for headspace effects on hydrolysis rate constants.

In the meantime, we will continue to use the $K_{h}$ values estimated from the data of Gossett (1987) and Gorgenyi et al. (2002) to calculate provisional rate constants. 


\subsection{Summary Discussion}

In general, the homogeneous data for CT obtained in this study agree well with those from higher temperatures, once the effects of partitioning into the vapor phase are taken into account. The net result is that slower rates of hydrolysis of CT in homogeneous solution are being measured at near-ambient temperatures than would have been predicted before this study. The precise size of the difference at ambient groundwater temperatures awaits further data. An estimate based on the current data yields homogeneous hydrolysis rates that are about three to four times slower at groundwater temperatures than would be predicted from the open literature.

In contrast to our previous reports, the evidence for an heterogeneous effect on CT hydrolysis rates is now confined to a single, marginally significant $(\mathrm{p} \approx 0.05)$ data point at $20^{\circ} \mathrm{C}$ that shows about a threefold increase over the rate in homogeneous solution. Extrapolation to $16^{\circ} \mathrm{C}$ yields nearly a five-fold increase in rate relative to that in homogeneous solution and a 130-year half-life for CT. However, the presence of Hanford Site sediment seems to have little effect on the rate of CT hydrolysis relative to that in homogeneous solution at temperatures of $30^{\circ} \mathrm{C}$ and higher. Based on analysis of the products, we are confident that the potential effect of the sediment is not due to biotic or to other redox-related degradation processes. Further, we see no difference in rates obtained in deionized water or in Hanford Site groundwater, only an effect of Hanford sediment. The new set of experiments with Hanford Site sediment started in FY 2009 at five temperatures from $20{ }^{\circ} \mathrm{C}$ to $40{ }^{\circ} \mathrm{C}$ should clarify the situation once usable data become available.

Homogeneous base-catalyzed hydrolysis rates for CF are different for phosphate-buffered systems than for systems where hydroxide is the only base present. The differences are attributed to parallel hydrolysis reactions caused by the nucleophilic character of the phosphate anions, particularly $\mathrm{HPO}_{4}{ }^{2-}$. Although the activation energies in the phosphate buffers are higher than in $\mathrm{NaOH}$, the rates observed are similar at groundwater temperatures. It is surmised that neither phosphate nor $\mathrm{HCO}_{3}{ }^{-}$, which is common in groundwater and has a nucleophilic character comparable to $\mathrm{HPO}_{4}{ }^{2-}$, significantly increases the rates of hydrolysis for CF over those observed in waters where they are absent.

The project has now developed sufficient rate data for neutral and base-catalyzed homogeneous hydrolysis of $\mathrm{CF}$ to calculate the relative impacts of temperature and $\mathrm{pH}$ on $\mathrm{CF}$ hydrolysis rates, and to estimate the rate at any given combination of these factors within the ranges tested. For example, the estimated half-life of $\mathrm{CF}$ in $\mathrm{pH}-7.8$ Hanford groundwater at $16^{\circ} \mathrm{C}$ is 3000 years. An increase in $\mathrm{pH}$ of about one unit or an increase in temperature of about $15^{\circ} \mathrm{C}$ will decrease the hydrolysis half-life of CF by an order of magnitude.

The hydrolysis rate constants obtained for $\mathrm{CF}$ in contact with various solid phases at $50^{\circ} \mathrm{C}$ varied by nearly a factor of twenty. This high sensitivity to type of solid is likely due to the different $\mathrm{pH}$ values maintained by the solid surface in contact with the aqueous phase. Additional experiments with careful pH control started in FY 2009 should verify this hypothesis once usable data are available. In contrast, very little effect of mineral type on CT hydrolysis rates was noted. This is consistent with the $\mathrm{pH}$ hypothesis for CF because CT hydrolyzes only by a neutral, $\mathrm{pH}$-independent mechanism.

At SUNY-Cortland, liquid-vapor partition coefficients $\left(\mathrm{K}_{\mathrm{lv}}\right)$ for $\mathrm{CT}$ and $\mathrm{CF}$ were measured at the temperatures and CF concentrations used in our homogeneous hydrolysis experiments. A smaller set of 
$\mathrm{K}_{\mathrm{lv}}$ values determined at PNNL by an entirely different approach were in excellent agreement with the SUNY data. Although at near-ambient temperatures good agreement with published values for the Henry's law constant $\left(\mathrm{K}_{\mathrm{h}}\right)$ was obtained, our values displayed a substantially weaker temperature dependence. The net impact of this would be to yield higher activation energies for the PNNL data, which require corrections for headspace partitioning, and these, in turn would affect the accuracy of predicted and extrapolated rates. We continue to evaluate the literature as well as our own experimental approaches and calculations to provide a rational explanation for the differences observed.

Since the inception of the project in FY 2006, a total of 120 experiments have been initiated (99 at PNNL and 21 at SUNY-Cortland). Of the 99 PNNL experiments, 53 have been completed, 31 are at intermediate or advanced stages of completion with three to four years of data in hand, and the remaining 15 are in the very early stages with roughly a year or less of data. These experiments have provided data to calculate 86 provisional rate constants. These are chiefly the high-pH and/or high-temperature treatments, for which hydrolysis rates are relatively fast. The remaining provisional rate constants will be determined as data from the lower-pH and lower-temperature experiments become available.

Sampling and analysis of these experiments in the next several years to complete this unique dataset will result in an improved predictive capability that incorporates the effects of both temperature and solid phase. Such a capability is essential to a scientifically based approach to remediation of CT and CF contamination in groundwater systems. 


\subsection{References}

Amonette JE, PM Jeffers, O Qafoku, CK Russell, TW Wietsma, and MJ Truex. 2009. Carbon

Tetrachloride and Chloroform Attenuation Parameter Studies: Heterogeneous Hydrolytic Reactions. PNNL-18735, Pacific Northwest National Laboratory, Richland, Washington.

Bouwer EJ and PL McCarty. 1983. "Transformations of halogenated organic compounds under denitrification conditions." Applied and Environmental Microbiology 45(4):1295-1299.

Criddle CS, JT DeWitt, D Grbic-Galic, and PL McCarty. 1990a. "Transformation of carbon tetrachloride by Pseudomonas sp. strain KC under denitrification conditions." Applied and Environmental Microbiology 56(11):3240-3246.

Criddle CS, JT DeWitt, and PL McCarty. 1990b. "Reductive dehalogenation of carbon tetrachloride by Escherichia coli K-12.” Applied and Environmental Microbiology 56(11):3247-3254.

Gorgenyi M, J Dewulf, and H Van Langenhove. 2002. “Temperature dependence of Henry's law constant in an extended temperature range." Chemosphere 48(7):757-762.

Gossett JM. 1987. "Measurement of Henry's law constants for $\mathrm{C}_{1}$ and $\mathrm{C}_{2}$ chlorinated hydrocarbons." Environmental Science \& Technology 21(2):202-208.

Heron G, TH Christensen, and CG Enfield. 1998. "Henry's law constant for trichloroethylene between 10 and $95{ }^{\circ}$ C." Environ. Sci. Technol. 32(10):1433-1437.

Jeffers PM, C Brenner, and NL Wolfe. 1996. "Hydrolysis of carbon tetrachloride." Environmental Toxicology and Chemistry 15(7):1064-1065.

Jeffers PM, P Coty, S Luczak, and NL Wolfe. 1994. "Halocarbon hydrolysis rates - a search for ionic strength and heterogeneous effects." Journal of Environmental Science and Health, Part A 29(4):821831.

Jeffers PM, LM Ward, LM Woytowitch, and NL Wolfe. 1989. "Homogeneous hydrolysis rate constants for selected chlorinated methanes, ethanes, ethenes and propanes." Environmental Science \& Technology 23(8):965-969.

Laine DF and IF Cheng. 2007. "The destruction of organic pollutants under mild reaction conditions: A review." Microchemical Journal 85(2):183-193.

McAuliffe CD. 1971. "GC determination of solutes by multiple phase equilibration." Chem. Tech. $1(1): 46-51$.

Oostrom M., ML Rockhold, PD Thorne, MJ Truex, GV Last, and VJ Rohay. 2007. "Carbon tetrachloride flow and transport in the subsurface of the 216-Z trench at the Hanford Site." Vadose Zone Journal 6(4):971-984. 
Phanikumar MS, DW Hyndman, DC Wiggert, MJ Dybas, ME Witt, and CS Criddle. 2002. "Simulation of microbial transport and carbon tetrachloride biodegradation in intermittently-fed aquifer columns." Water Resources Research 38(4):1033, doi: 10.1029/2001WR000289.

Riley RG, DS Sklarew, CF Brown, PM Gent, JE Szecsody, AV Mitroshkov, and CJ Thompson. 2005. Carbon Tetrachloride and Chloroform Partition Coefficients Derived from Aqueous Desorption of Contaminated Hanford Sediments. PNNL-15239, Pacific Northwest National Laboratory, Richland, Washington.

Schwarzenbach RP, PM Gschwend, and DM Imboden. 1993. Environmental Organic Chemistry. John Wiley \& Sons, New York.

Staudinger J and PV Roberts. 2001. “A critical compilation of Henry's law constant temperature dependence relations for organic compounds in dilute aqueous solutions." Chemosphere 44(4):561-576.

Swain CG and CB Scott. 1953. Quantitative correlation of relative rates. "Comparison of hydroxide ion with other nucleophilic reagents toward alkyl halides, esters, epoxides and acyl halides." Journal of the American Chemical Society 75(1):141-147.

Tatara, GM, MJ Dybas, and CS Criddle. 1993. "Effects of medium and trace metals on kinetics of carbon tetrachloride transformation by Pseudomonas sp. strain KC." Applied and Environmental Microbiology 59(7):2126-2131.

Truex MJ, CJ Murray, CR Cole, RJ Cameron, MD Johnson, RS Skeen, and CD Johnson. 2001. Assessment of Carbon Tetrachloride Groundwater Transport in Support of the Hanford Carbon Tetrachloride Innovative Technology Demonstration Program. PNNL-13650, Pacific Northwest National Laboratory, Richland, Washington. 


\section{Distribution}

No. of

Copies

\section{Offsite}

G. Chamberlain

Office of Groundwater and Soil

Remediation

EM-32/Cloverleaf Building

U.S. Department of Energy

1000 Independence Avenue SW

Washington, DC 20585-2040

P. M. Jeffers

c/o Department of Chemistry

Bowers Hall

SUNY-Cortland

P.O. Box 2000

Cortland, NY 13045
No. of

\section{Copies}

\section{Onsite}

2 DOE Richland Operations Office

K. M. Thompson

A6-38

A. C. Tortoso

A6-38

\section{CH2M HILL Plateau Remediation Company}
M. E. Byrnes
R3-60
E. J. Freeman
R3-50
S. W. Petersen
R3-50
V. J. Rohay
H8-15
S. A. Simmons
R3-60
C. Sutton
R3-50

13 Pacific Northwest National Laboratory

$\begin{array}{ll}\text { J. E. Amonette } & \text { K8-96 } \\ \text { M. D. Freshley } & \text { K9-33 } \\ \text { J. S. Fruchter } & \text { K6-96 } \\ \text { D. R. Humphrys } & \text { K8-96 } \\ \text { G. V. Last } & \text { K6-81 } \\ \text { M. Oostrom } & \text { K9-33 } \\ \text { O. Qafoku } & \text { K8-96 } \\ \text { M. L. Rockhold } & \text { K9-36 } \\ \text { C. K. Russell } & \text { K8-96 } \\ \text { P. D. Thorne } & \text { K6-96 } \\ \text { M. J. Truex } & \text { K6-96 } \\ \text { M. D. White } & \text { K9-33 } \\ \text { T. W. Wietsma } & \text { K8-96 }\end{array}$




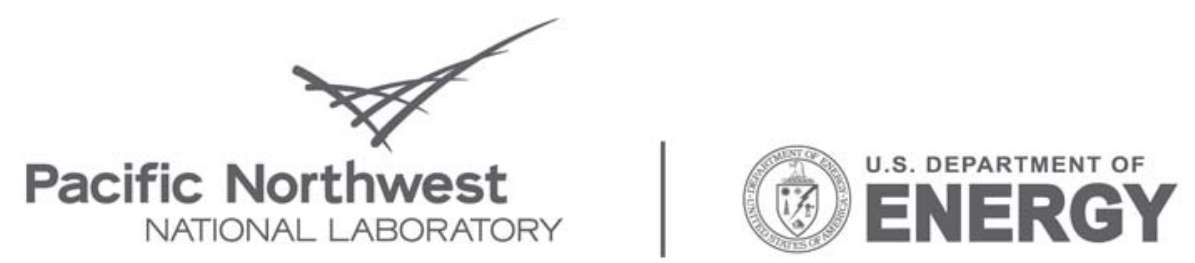

Proudly Operated by Battelle Since 1965

902 Battelle Boulevard

P.O. Box 999

Richland, WA 99352

1-888-375-PNNL (7665)

www.pnl.gov 